Discussion Paper No. 11-068

\title{
Strategic Pricing, Market Entry and Competition: Evidence from German Electricity Submarkets
}

Vigen Nikogosian and Tobias Veith

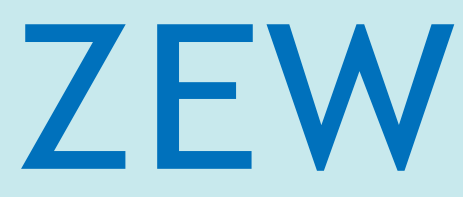

Zentrum für Europäische Wirtschaftsforschung $\mathrm{GmbH}$ Centre for European Economic Research 
Discussion Paper No. 11-068

\section{Strategic Pricing, Market Entry and Competition: Evidence from German Electricity Submarkets}

Vigen Nikogosian and Tobias Veith

Download this ZEW Discussion Paper from our ftp server:

http://ftp.zew.de/pub/zew-docs/dp/dp11068.pdf

Die Discussion Papers dienen einer möglichst schnellen Verbreitung von neueren Forschungsarbeiten des ZEW. Die Beiträge liegen in alleiniger Verantwortung der Autoren und stellen nicht notwendigerweise die Meinung des ZEW dar.

Discussion Papers are intended to make results of ZEW research promptly available to other economists in order to encourage discussion and suggestions for revisions. The authors are solely responsible for the contents which do not necessarily represent the opinion of the ZEW. 


\section{Non-technical Summary}

German electricity submarkets for residential customers have been liberalized by the end of the 1990s. Since then a large number of new providers has entered former monopolistic markets, which are first and foremost retail markets. However, only a low share of households in Germany has switched to a competitive contract. Following the Monitoringbericht 2008 of the German energy regulator Bundesnetzagentur about 60 percent of households have not switched to an alternative contract, even ten years after the liberalization. These households are served with incumbents' standard contracts, the so-called "Grundversorgungsverträge". Usually, standard contracts are offered at significantly higher prices than competitive contracts due to high customers' switching costs. In this paper we follow the question how the standard contract price or the price-cost markup for this contract could be used to influence market structure.

Following the Limit Pricing theory, we show that retail competition in terms of the number of competitors depends on the standard contract price and that the provider of this contract type might use the price as an instrument to affect competition in its home market ceteris paribus. By reducing the standard contract price customers' net benefits of switching to an alternative contract could be reduced. Thus, market entry might be not profitable for less efficient supplier. We would then expect a lower number of electricity suppliers in markets with lower standard contract prices. Whether the low-price strategy is profit-increasing for the incumbent depends on the behavior of the customers: With a lower standard contract price also the price-cost markup is lower. On the other hand, lower numbers of customers are willing to switch to competitive contracts.

We analyze the limit pricing idea using a simultaneous equations approach and employ data for all geographically separated German retail electricity submarkets. We control for alternative regional impact characteristics such as customer concentration, purchasing power, grid characteristics as well as the distribution charge, which providers have to pay for electricity provision in a market. Our estimation results show a significant effect of the standard contract price (or price-cost markup) on the number of offered contracts and number of the competitors offering contracts to low consumption customers (one-person households) in a distinct market. However, the number of the competitors offering contracts to households with higher consumption is not affected by the standard contract price but by the distribution charge, which is in line with the theoretical literature. Contracts per provider instead show that providers in a market with a lower number of competitors offer more contracts given the price-cost markup. Thus, our results show that, besides the distribution charge, incumbents can also affect competition due to customers' high relative switching costs. 


\section{Das Wichtigste in Kürze (Summary in German)}

Seit der Liberalisierung des deutschen Strommarktes Ende der neunziger Jahre sehen sich frühere regionale Monopolisten neu eingetretenen Konkurrenten gerade in Endverbrauchermärkten gegenüber. Der Monitoringbericht 2008 der Bundesnetzagentur zeigt, dass viele Jahre nach der Liberalisierung etwa 60 Prozent der Haushalte noch keinen Vertragswechsel durchgeführt haben. Diese Haushalte werden durch sogenannte Grundversorgungsverträge des größten Anbieters im Markt versorgt. Grundversorgungsverträge werden wegen der geringen Wechselbereitschaft der Haushaltskunden meist zu signifikant höheren Preisen angeboten als wettbewerbliche Verträge. In diesem Papier untersuchen wir die Frage, ob daher Grundversorgungsvertragspreise genutzt werden, um den regionalen Wettbewerb um Haushaltskunden zu beeinflussen.

Wir zeigen in einem einfachen theoretischen Modell, dass die Anzahl der Wettbewerb bzw. die Entscheidung in einen Markt einzutreten durch die Höhe des Preises des Grundversorgungsvertrags beeinflusst werden kann. Mit einem niedrigeren Grundversorgungspreis kann einerseits der Nutzen für Nachfrager aus einem Wechsel zu einem alternativen Vertrag verringert werden. Daher könnte sich ceteris paribus der Markteintritt für weniger effiziente Wettbewerber nicht lohnen und man sollte eine geringere Anzahl von Wettbewerbern erwarten. Der Erfolg eines niedrigeren Preises ist allerdings vom Verhalten der Nachfrager abhängig: Ein niedrigerer Standardvertragspreis resultiert in einer geringeren Preis-Kosten-Marge, macht den Standardvertrag allerdings attraktiver für Nachfrager.

Im nächsten Schritt untersuchen wir empirisch, inwieweit eine solche Limit Pricing Strategie der Grundversorger existiert. Dazu verwenden wir Daten für alle deutschen Strommärkte für Haushaltskunden und kontrollieren für regionale Einflussfaktoren wie Nachfragerkonzentration, Kaufkraft, Netzcharakteristika und das regulierte Netznutzungsentgelt, die Durchleitungsgebühr für Strom. Unsere Schätzergebnisse zeigen einen hoch signifikanten Einfluss des Preises des Grundversorgungsvertrags auf die Anzahl der angebotenen Verträge und die Anzahl der neuen Anbieter für Haushaltskunden mit geringem Verbrauch. Für das Kundensegment mit höherem Verbrauch sind keine Effekte zu beobachten. Unsere Ergebnisse stützen darüber hinaus die aus der theoretischen Literatur bekannte Hypothese, dass ein höheres (reguliertes) Netznutzungsentgelt einen negativen Einfluss auf die Anzahl der Wettbewerber im nachgelagerten Markt hat. Anbieter, die trotz eines höheren Netznutzungsentgeltes in den Markt eintreten, bieten ceteris paribus mehr Verträge an und schließen damit die Lücke aus einer niedrigeren Zahl an Wettbewerbern. Wir können daher zeigen, dass neben den Netznutzungsentgelten hohe relative Wechselkosten und das strategische Verhalten der ehemaligen Monopolisten die Markteintritte beeinflussen können. 


\section{Strategic Pricing, Market Entry and Competition: Evidence from German Electricity Submarkets}

- Vigen Nikogosian ${ }^{12}$

Tobias Veith ${ }^{3}$

In German electricity submarkets for residential customers standard contracts offered by former monopolists are the more costly option for customers who have not switched to an alternative contract yet. As most German households are served with this contract type we follow the Limit Pricing theory and show that standard contract price could be used as an instrument to affect competition, in terms of market entries, in the related market. We theoretically derive the optimal price-setting behavior of a price-discriminating incumbent provider and show that under particular circumstances reducing the standard contract price could increases the incumbent's profit. We then analyze our theoretical findings employing data for German retail electricity submarkets using simultaneous equation approach and can find support for our hypothesis. In particular for customers with low consumption and high relative switching costs the results show that the standard contract price can affect market entry whereas for high consumption level customers we have to reject our hypothesis.

L11, L13, L43, L94 - barrier to entry, first-mover advantage, price discrimination

\footnotetext{
${ }^{1}$ ZEW Centre for European Economic Research, L7,1, D-68161 Mannheim, Tel.: +49-621-1235 386, nikogosian@zew.de

${ }^{2}$ WHU- Otto Beisheim School of Management, Burgplatz 2, D-56179 Vallendar

${ }^{3}$ ZEW Centre for European Economic Research, L7,1, D-68161 Mannheim, Tel.: +49-621-1235 296, veith@ zew.de
} 


\section{Introduction}

Electricity markets in Europe were liberalized during the 1990s. Since then new entrants are allowed to enter the market and offer energy contracts to customers of former national or regional monopolists. However, particularly in Germany only a very low number of residential customers have switched to an alternative provider. Following the "Monitoringbericht 2008", an annual survey by the German regulator Bundesnetzagentur, only 6.4 percent of all German households switched to an alternative provider, 34 percent switched to an alternative incumbent contract and about 60 percent stayed with incumbents' standard contracts.

The largest retail provider - that is the former monopolist in each local submarket, is obliged to offer a particular contract type, namely the standard contract, due to universal service obligations (USOs). As the retail markets are not regulated each incumbent can individually determine its standard contract price. The prices for standard contracts are higher than for alternative contracts offered in the markets. Additionally, incumbents offer alternative contracts to customers who are more willing to switch. Thus, they charge higher prices from customers with high switching costs while they offer low-price contracts to those customers who are willing to switch their contract or supplier. This behavior is a form of third degree price discrimination (see e.g. Schmalensee (1981)). As customers in the standard contract seem to be highly price-insensitive we analyze the hypothesis that standard contract price adjustments could be used as a strategic instrument to affect competition in terms of number of competitors or contracts in retail markets.

We adopt the idea of limit pricing models as introduced in Bain (1949) and extended in Dixit (1979) and rearrange it to the framework observed in German retail energy markets for household customers. In a simple theoretical model of market deterrence we first show that the level of the standard contract price might have an impact on the number of contracts in the market. However, this is possible only if the incumbent, as a first mover, can commit itself to a price strategy. Thus, if the strategy of the price leader is binding, market deterrence might occur.

Using data for numerous German geographically separated electricity submarkets we test the theoretical outcome. We determine the impact factors of distribution charges and standard contract prices separately and analyze how the difference in standard contract prices and distribution charge, known as the price-cost markup influences the number of competitors, the number of contracts with prices below the standard contract price and the number of contracts per provider in about 850 local markets. We conduct this analysis for three alternative user groups (demanding 1500, 2800 and $4000 \mathrm{kWh}$ per year) as proposed in Salies and Waddams Price (2004) or Salies (2008). Note that the distribution charges are cost-based regulated, thus, the only strategic instrument is the incumbent's retail price.

We find that the number of contracts in a local market is on average positively affected by the price-cost markup of the standard contract. However, we do not observe a clear evidence for market deterrence, as the number of entrants is negatively affected by the price-cost markup only for high consumption level (4000 kWh). Thus, our empirical results provide evidence for the standard contract price being an additional strategic instrument to affect the number of contracts, and thus, the extent of price discrimination, but not for market entry.

The paper is organized as follows: We first give an overview of the existing literature. Next we present our theoretical model based on the situation observed for Germany followed by the discussion 
on the outcomes of the model. In section 4 we describe the data and derive the estimation model. Section 5 provides the estimation results and their discussion. The last section concludes the paper.

\section{Related Literature}

Electricity markets are in the focus of multiple strands of literature. While there is a non-exhaustive range of literature on wholesale competition, production and the challenges of transmission, we mainly concentrate on the description of retail competition and entry barriers.

Only a few empirical studies consider the effects of market liberalization on incumbents' market power. For example, Salies and Waddams Price (2004) analyze how competition in UK retail energy markets is affected by the market power of single providers. They find that prices are determined not only by customer characteristics and cost factors but particularly also by incumbency.

Salies (2008) takes up these results and analyzes which factors affect competition and thus contracts offered to private customers. He finds that providers first differentiate between rural and urban customers as prices are significantly lower in more densely populated areas. Concerning grid characteristics he identifies underground cables to be a "price-reducer" since underground cables are less affected by climate impact factors. Moreover, Salies shows that transmission charges on both higher voltage and distributional level also positively affect retail prices. Finally, he identifies significantly higher prices for incumbents. ${ }^{4}$

The theoretical literature distinguishes between vertical and horizontal market entry deterrence. A vertically integrated provider controls an essential input (distribution network) for downstream competitors and is also involved in downstream competition. Because of this exceptional position it is able to influence downstream prices or quality aspects of goods by altering characteristics of the essential input. The issue of vertical foreclosure is extensively discussed in Rey and Tirole (2003). As providers have to pay a network access charge it could be used to foreclose downstream competitors as is shown in Stiglitz (1979). To prevent such an abuse network (distribution) charges are regulated and have to be paid by all downstream supplying firms regardless of their vertical relations with distribution network operators.

In contrast to vertical foreclosure horizontal foreclosure means a firm's strategic pricing that can force competitors out of a market or used to deter entry. One particular theory in this context is the limit-pricing theory which focuses on a monopolist who chooses a lower price under the threat of entry than in a closed-market situation. Bain (1949) argues that a price chosen sufficiently low prevents new providers from market entry. Despite the criticism as it could not really be proven in reality (since the prices adjust after the market entry and a monopolist's price choice is flexible in itself), further theoretical studies provide alternative ideas how price reduction could be used as an instrument to deter market entry (Dixit, 1979, 1980, Spence, 1977 and Milgrom and Roberts, 1982b). Pricing strategies to foreclose competitors in a market are examined mainly under the umbrella of predatory pricing (see e.g. Milgrom and Roberts, 1982a). In this context the predator reduces its price to drive competitors out of the market. In the short run prices could be chosen even

\footnotetext{
${ }^{4}$ A further central aspect of this paper is the analysis of the correlation of vertical integration and incumbent prices. The author finds vertical integration aspects to be of less importance than regional aspects. We want to address this research question in a subsequent paper for German electricity markets where we use data for the incumbent operators and compare price differences of standard contracts with regard to vertical integration with grid owners, the four high-voltage companies and municipal firm alliances.
} 
below marginal costs, thus inducing losses that could be recouped after competitors have left the market. However, predation falls under the treatment of national and EU antitrust law.

Klemperer (1987) shows that in markets with high switching costs the incumbent can lower the output and deter market. He too suggests that the larger the consumer base in the pre-entry period the less likely is an aggressive behavior of the incumbent to attract new customers and compete with the entrant when price discrimination between new and old costumers is not possible. To deter market entry the incumbent could "limit over-price" in the pre-entry period and then compete with the entrant in the second period. This behavior might weaken market entry incentives.

Our theoretical model refers to the idea of limit pricing in retail markets, where the price is not regulated, the former monopolists are the current incumbents in their local markets, and distribution charges for the electricity grid are the same for all firms as they are regulated. The assumption in our model is that the incumbent move first by setting a binding price for its standard contract. The potential entrants observe the prices and decide whether to enter or not. In contrast to Klemperer (1987) we assume that the incumbent is able to discriminate between customers with low and high switching costs but we do not model the switching costs explicitly. Furthermore, the assumption of price competition might be appropriate as the total market demand is assumed to be (at least in the short run) inelastic in the electricity markets for household customers and new customers do not enter the market (market expansion does not occur due to market entry). We want to show that limit-pricing can be rational for former monopolists in the electricity markets and test this hypothesis using cross-sectional data for household customers in Germany. As suggested in the literature on market entry, for example in Bresnahan and Reiss (1990), we too assume that a market can accommodate a certain number of newcomers that enter as long as the expected profits are non-negative.

\section{Competition in the Retail Market}

\subsection{Description of the German Electricity Market}

The German electricity market is much more geographically decentralized than other European electricity markets. In the production and high voltage transmission system four transmission system operators (TSOs) exist which are active in their regionally separated high voltage areas. At the low voltage level, there are about 850 regionally separated markets for household electricity provision. ${ }^{5}$ These are delineated by the geographical area supplied by only one distribution operator. In each market only one distribution operator and one downstream incumbent is active. The definition of the relevant market for household customers is applied by the German Competition Authority in cases of market power abuse. We follow another market definition for our empirical analysis, which is described in the Data section. Figures 1 and 2 provide an overview of regional separation: ${ }^{6}$ Figure 1 displays the four highest voltage areas of E.On ${ }^{7}$, EnBW, RWE and Vattenfall Europe. ${ }^{8}$ The E.On area is the largest, the EnBW the smallest of the four regions. The TSOs keep about 85 percent of the electricity production capacities in Germany (in 2008). Moreover, long-run supply-agreements

\footnotetext{
${ }^{5}$ See the Monitoringbericht 2008.

${ }^{6}$ Data for the graphs are provided by E'net.

${ }^{7}$ Recently E.on sold its transmission grid to TenneT (in 2010). As we employ Data from 2008 we consider E.on as the owner of the Grid.

${ }^{8}$ Note that there are also transmission regions close to the German border which are operated either by foreign transmission grid providers or by smaller providers.
} 
and over the counter trade with regional energy providers exist and, thus, only about one fifth of electricity trade takes place at the European Energy Exchange (EEX) in Leipzig.

On the distribution level local grid operators were mainly integrated with retail energy providers but were forced to disentangle production, distribution and retail into legally separated companies by the introduction of legal unbundling in 2007 to prevent discrimination against the entrants. ${ }^{9}$

All in all, former monopolistic energy providers still keep the absolute majority of customers in their home markets mainly in standard contracts but also in newly installed, more competitive contracts. On average more than 40 additional providers are active in each electricity market with a market share of less than 10 percent of all retail customers. ${ }^{10}$ Switching away from incumbent to a competitor is still very rare. Figure 2 displays the 850 separated distribution areas. Two equally large regions exist, one in North-Eastern Germany and one in Bavaria. The first mainly covers the less densely populated area in Germany. In contrast, the most-densely populated area, the RhineRuhr area in Western Germany, is separated into a multitude of very small distribution areas. For the access to one of these local markets electricity providers have to pay a cost-based regulated distribution charge. ${ }^{11}$ This distribution charge is a two-part tariff composed of two fixed-part elements which are a fixed annual charge and a metering charge. The variable charge depends on the amount of consumed energy. ${ }^{12}$ Distribution charges are market specific and the same for all suppliers.

Competitors that entered the market are mostly newcomers that were not active in electricity markets before the liberalization. Beside the newcomers, a few former monopolists decided to expand in new geographically separated markets and also low-cost suppliers that have been set up mostly by the four major electricity producing companies, entered particular markets. Electricity contracts for household customers are mostly equipped with specific characteristics. For example, customers can choose contracts with different shares of renewable energy or contract duration. Additionally, there are contracts with particular bonus schemes or price reductions. Product differentiation is one of the crucial factors to relax intense price competition. However, all of these contract characteristics only slightly affect provision costs. ${ }^{13}$ In contrast to these recent types of differentiation, the standard

\footnotetext{
${ }^{9}$ The obligation to separate the grid from other activities, such as retail or production, applies only for firms with more than 100.000 customers. Firms which do not reach this threshold are allowed to remain within the same company.

${ }^{10}$ Note that these alternative providers are much more successful with regard to industrial customers.

${ }^{11}$ Regulation changed in 2009 from cost-based regulation to revenue-cap regulation.

${ }^{12}$ Since 2009 the distribution charges are incentive based regulated (revenue cap). In our empirical analysis, however, we employ cost-based regulated distribution charges from 2008.

${ }^{13} \mathrm{We}$ do not have any production cost information for our analysis below. Therefore, we have introduced contract dummies and, alternatively, company dummies to cover (among others) production or procurement costs. These dummies were of no significance for prices offered to customers. Also with other estimation model specifications we find only a low number of dummies being significant which, in our opinion, is a sign for strong similarities among providers taking into account the range of other variables used in our study.
} 
Figure 1: Regional separation of the German Electricity Transmission Market ${ }^{14}$

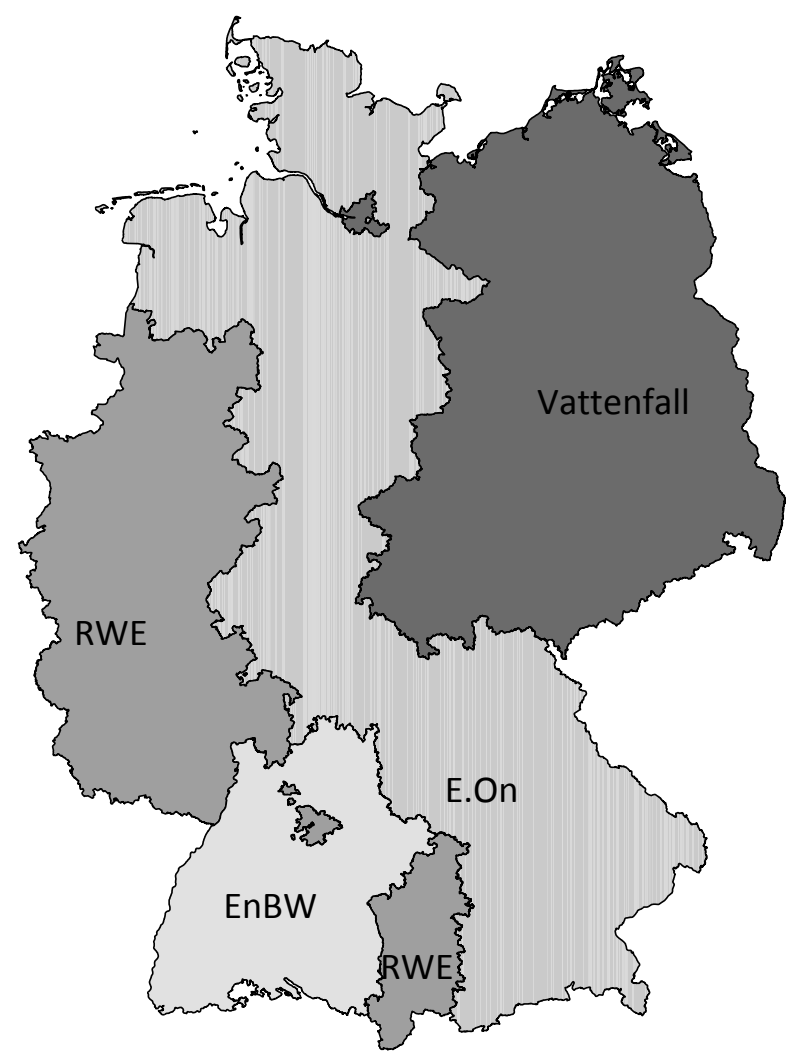

Figure 2: Regional separation of the German Electricity Distribution Market

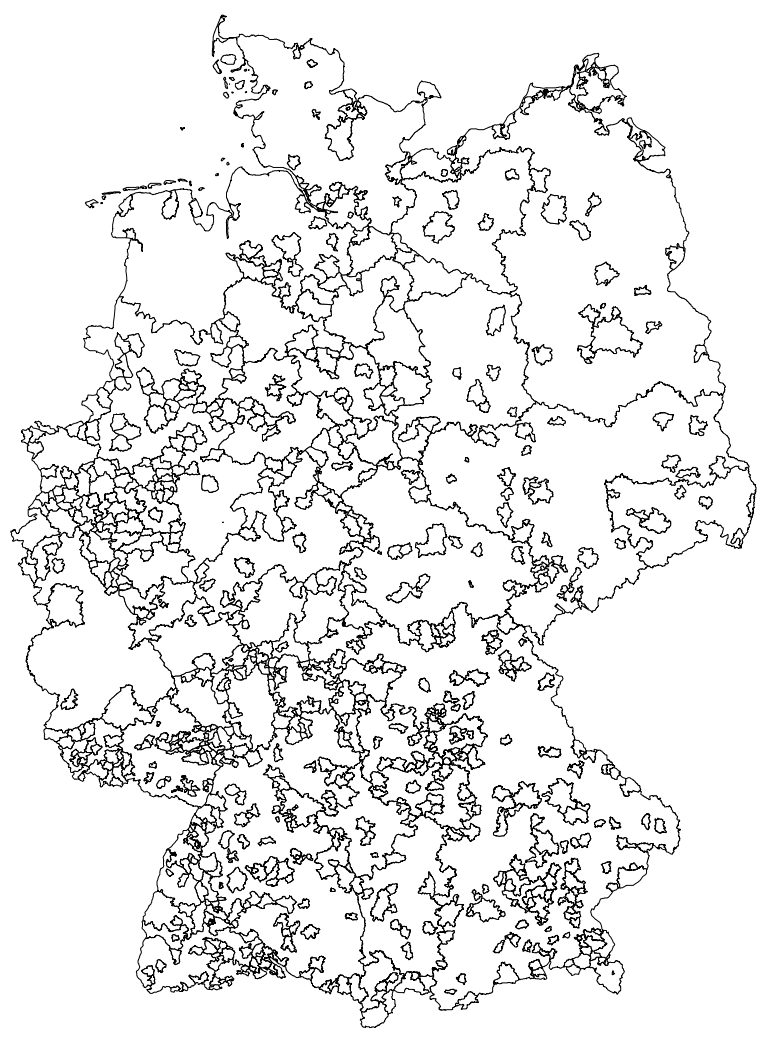

have significantly less (or no) "add-on" characteristics but are offered at a higher price. By law these have to be offered by the energy provider which serves the majority of household customers

${ }^{14}$ All maps in this paper are generated using GfK GeoMarketing information. 
in a region. It could be interpreted as a "fall-back" option for customers who have switched to an alternative contract. They automatically return to the standard contract either if their new provider leaves the market or if their contract is deleted and customers in this contract have not decided where to switch ( $\S \S 36-38$, Energiewirtschaftsgesetz (EnWG)). However, as already mentioned above, the Monitoringbericht of the German regulator Bundesnetzagentur reports that about 60 percent of all German households have not switched yet (c.f. Monitoringbericht 2008). Note that in all German retail markets former monopolists are still the providers of standard contracts. Nevertheless, they are also allowed to offer alternative contracts. These contracts are much more similar to those of new competitors but they are also a successful instrument for binding potential "switchers" as most switching households stay with their incumbent providers (34 percent).

\subsection{Theoretical model}

In the following, we consider sequential price competition with differentiated products and the threat of potential market entry in a three stage game. Differentiated contracts for electricity supply are offered by the dominant provider and one alternative competitor. We assume that the dominant provider offers two types of contracts, a standard contract at price $p_{s t}$ and a competitive contract at price $p_{1}$ for customers with low switching costs that are willing to switch. ${ }^{15}$ The competitor offers one contract at price $p_{2}$. We assume that one further (potential) competitor will enter the market with only one contract at a price $p_{3}$ if its expected profits are larger than zero. The timing of the game is as follows: first, the incumbent determines the price for the standard contract. Then the competitor and the potential entrant observe this price and the potential competitor decides to enter the market or not. Finally, all providers choose their competitive contract prices simultaneously. With these assumptions, we follow the Limit Pricing theory with fully informed firms maximizing their profits given that the strategy of the price leader (incumbent) is binding. Thus, the incumbent can commit itself to a price for its standard contract and the competitors consider this price strategy as credible. If for example the price leader decreases its price for the standard contract (in contracts to alternative contracts) then an immediate increase is not profitable since a number of customers could prompt switching to another contract or other electricity supplier. ${ }^{16}$

Customers are of mass 1 and individually ask for an identical quantity of electricity. ${ }^{17}$ All customers who have not yet switched are in the standard contract st. For reasons of simplicity we assume that customers switch to an alternative contract if the net utility increase of switching is sufficiently large. The demand for contract $i \in\{1,2,3, s t\}$ is then defined as function of contract prices in the market. We keep the usual price-demand assumptions:

\footnotetext{
${ }^{15}$ Note that we do not model the switching costs explicitly. The heterogeneity in the switching costs is implicitly captured in the demand and price functions of the offered contracts.

${ }^{16}$ Since the standard contract can be switched monthly, incumbents seldom adjust prices because in that case customers have to be informed about the price change. Thus, compared with other contracts with longer contract duration, we observe rare price adjustments for the standard contract. Usually, the majority of the incumbents announce their price adjustments simultaneously. This could mitigate switching effects because of the announcements in the popular press and customers perception that prices are affected in the whole industry and therefore switching to another supplier is not beneficial.

${ }^{17} \mathrm{We}$ assume total market demand to be price inelastic in the short run.
} 


$$
N_{i}=N_{i}\left(p_{i}\right) \text { with } \frac{\partial N_{i}}{\partial p_{i}}<0, \quad \mathrm{i}=1,2,3, s t
$$

Prices are strategic complements, $\frac{\partial p_{i}}{\partial p_{-i}} \geq 0$, and cross-price effects are positive regardless of other contracts. The absolute own-price effect on demand is larger than the cross-price effect:

$\frac{\partial N_{i}}{\partial p_{-i}}>0,\left|\frac{\partial N_{i}}{\partial p_{-i}}\right|<\left|\frac{\partial N_{i}}{\partial p_{i}}\right| \quad i,-i=1,2,3, s t ; i \neq-i$

We first analyse the situation without strategic intervention of the incumbent and then show that under particular conditions it could be profitable for an incumbent to offer a standard contract at a lower price to keep a competitor out of the market.

\subsubsection{Optimal pricing with market entry}

We solve the game by backward induction and start where the potential competitor decides to enter the market. The profit functions are then:

$$
\begin{aligned}
& \pi_{1}=\left(p_{s t}-d c-c_{1}\right)(1-N)+\left(p_{1}-d c-c_{1}\right) N_{1}-F_{1} \\
& \pi_{2}=\left(p_{2}-d c-c_{2}\right) N_{2}-F_{2} \\
& \pi_{3}=\left(p_{3}-d c-c_{3}\right) N_{3}-F_{3}
\end{aligned}
$$

with $N=N_{1}+N_{2}+N_{3}$. Thus, $N$ is defined as the total number of customers who have "switched" from the standard contract to competitive contracts. All providers bear marginal $\operatorname{costs} c_{i}$, fixed costs $F_{i}, i=1,2,3$, and an identical, regulated per-unit distribution charge $d c$. We further assume that $F_{2}<F_{3}$ to ensure that the potential entrant is the one targeted by the standard contract, as the entry condition must hold. The rational for this assumption is that first the higher-cost competitors are affected by incumbent's pricing behaviour

Beginning with the last stage, the optimal prices are determined by the FOC of the profit functions with respect to competitive prices. Thus, we obtain the implicit price reaction functions for the competitive contracts

$$
\begin{aligned}
& \frac{\partial \pi_{1}}{\partial p_{1}}=N_{1}\left(p_{s t}, \cdot\right)-\left(p_{s t}-d c-c_{1}\right) \frac{\partial N\left(p_{s t}, \cdot\right)}{\partial p_{1}}+\left(p_{1}-d c-c_{1}\right) \frac{\partial N_{1}\left(p_{s t}, \cdot\right)}{\partial p_{1}}=0 \\
& \frac{\partial \pi_{i}}{\partial p_{i}}=N_{i}\left(p_{s t}, \cdot\right)+\left(p_{i}-d c-c_{i}\right) \frac{\partial N_{i}\left(p_{s t}, \cdot\right)}{\partial p_{i}}=0
\end{aligned}
$$

$i=2,3$.

Thus, we get the best response functions for the competitors' contracts and for the incumbent's competitive contract as $p_{i}^{R}=p_{i}^{R}\left(p_{s t}, p_{1}, p_{-i}, c_{i}, d c\right), i,-i=2,3, i \neq-i$ and $p_{1}^{R}=p_{1}^{R}\left(p_{s t}, p_{2}, p_{3}, c_{1}, d c\right)$.

In the second stage the potential competitor observes the standard contract price $p_{s t}^{*}$. It only enters the market if the zero condition holds: 


$$
\pi_{3}\left(p_{s t}, p_{1}\left(p_{s t}\right), p_{2}\left(p_{s t}\right), p_{3}\left(p_{s t}\right)\right) \geq 0 \text {. }
$$

Finally, given the implicit price reaction functions of the last stage and the entry decision of the potential customer we implicitly derive the optimal standard contract price:

$$
\frac{\partial \pi_{1}}{\partial p_{s t}}=1-N-\left(p_{s t}-d c-c_{1}\right) \frac{\partial N}{\partial p_{s t}}+\left(p_{1}^{R}-d c-c_{1}\right) \frac{\partial N_{1}}{\partial p_{s t}}+N_{1} \frac{\partial p_{1}^{R}}{\partial p_{s t}}=0
$$

The incumbent takes into account the (direct) price effect, the first two terms, and, additionally, an (indirect) price effect on its competitive contract price, the last term. Note that the incumbent uses its competitive contract to prevent customers from switching to an alternative provider. The higher the standard contract price the more customers choose an alternative contract. A higher demand for alternative contracts raises the prices for these contracts. The magnitude of this price effects depends on $\frac{\partial p_{1}^{R}}{\partial p_{s t}}$. If, for example, customers with standard contracts have high switching costs then the incumbent can raise the standard contract price without having a high impact on its competitive price. Thus, the higher the difference between the switching costs the bigger the gap between prices paid by different customer groups with different switching costs. ${ }^{18}$ When choosing its standard contract price the incumbent has to deal with this trade-off between the standard contract price effect and the indirect effect on its own competitive contract. From (3) one can derive the equilibrium standard contract price as $p_{s t}^{*} \equiv p_{s t}^{*}\left(d c, c_{1}, c_{2}, c_{3}\right)$ which only depends on the (exogenously given) distribution charge and the variable costs of electricity provision.

\subsubsection{Optimal pricing with entry deterrence}

As mentioned above, we assume that competitors consider the standard contract price set by the incumbent in the first stage as binding. Depending on the price elasticity the loss caused by a standard contract price reduction is lower than the loss of a lower demand if a new competitor enters the market. In this scenario, the alternative standard contract price $p_{s t}^{A}\left(<p_{s t}^{*}\right)$ has to satisfy the following foreclosure condition: $\pi_{3}\left(p_{s t}^{A}, p_{1}^{A}, p_{2}^{A}, p_{3}^{A}\right)<0$. A indicates the case of market deterrence.

If provider 3 stays out of the market the remaining profit functions are as follows:

$$
\begin{aligned}
& \pi_{1}^{A}=\left(p_{s t}^{A}-d c-c_{1}\right)\left(1-N^{A}\right)+\left(p_{1}^{A}-d c-c_{1}\right) N_{1}^{A}-F_{1} \\
& \pi_{2}^{A}=\left(p_{2}^{A}-d c-c_{2}\right) N_{2}^{A}-F_{2}
\end{aligned}
$$

with $N^{A}=N_{1}^{A}+N_{2}^{A}, p_{s t}^{A}<p_{s t}^{*}$.

Thus, the new price reaction functions for the competitive contracts are $p_{1}^{A R}=p_{1}^{A R}\left(p_{s t}^{A}, p_{2}^{A}, c_{1}, d c\right)$ for the competitive incumbent contract and $p_{2}^{A R}=p_{2}^{A R}\left(p_{s t}^{A}, p_{1}^{A}, c_{2}, d c\right)$ for the competitor's contract. In case of only two competitive contracts in the market and low standard contract price the demand for each contract is higher: $N>N^{A}, N_{i}^{A} \geq N_{i}, i=1,2$.

Provider 3 would enter the market if its resulting profit just equals the profit from its outside option:

${ }^{18}$ This result reflects the theoretical findings of Varian (1980) in a sale model. 


$$
\pi_{3}^{A}=\left(p_{3}^{A}-d c-c_{3}\right) N_{3}^{A}-F_{3}=0
$$

By assuming continuous price reaction functions we calculate the threshold standard contract price as the standard contract price with entry minus the standard contract price change due to the price reaction of potential competitor's contract:

$$
p_{s t}^{A}=p_{s t}^{*}-\frac{\left(p_{3}^{*}-p_{3}^{A}\right)}{\partial p_{3}^{R} / \partial p_{s t}}
$$

Rearranging the threshold condition in (5) and replacing it into (6) yields:

$$
p_{s t}^{*}-p_{s t}^{A}=\frac{p_{3}^{*}}{\partial p_{3}^{R} / \partial p_{s t}}-\left(\frac{\left(d c+c_{3}\right) N_{3}^{A}+F_{3}}{\left(\partial p_{3}^{R} / \partial p_{s t}\right) N_{3}^{A}}\right)
$$

The gap between the optimal standard contract price with three providers and the optimal standard contract price for entry deterrence depends mainly on two factors: first, the competitor's price reaction function and, second, the competitor's marginal and fixed costs. The higher the cross-price effect and the higher the marginal costs, the lower the relevant effort for the incumbent. Obviously, the price-cost margin is lower with market deterrence than with market entry: $\frac{p_{s t}^{*}-d c-c_{1}}{p_{s t}^{*}}>\frac{p_{s t}^{A}-d c-c_{1}}{p_{s t}^{A}}$.

From the incumbent's perspective a price deviation is only profitable if $\Delta^{A}=\pi_{1}^{A}-\pi_{1}^{*}>0$, i.e. if the foreclosure profit exceeds the equilibrium profit with two competitors. Subtracting the profit in the static equilibrium situation from the one in the foreclosure situation and rearranging terms yields:

$$
\begin{aligned}
\Delta_{1}^{A}= & \left(p_{1}^{A} N_{1}^{A}-p_{1}^{*} N_{1}\right)+\left(p_{s t}^{*} N-p_{s t}^{A} N^{A}\right)-\left(p_{s t}^{*}-p_{s t}^{A}\right) \\
& -\left(d c+c_{1}\right)\left(\left(N-N_{1}\right)-\left(N^{A}-N_{1}^{A}\right)\right)
\end{aligned}
$$

The sign of the first term is undetermined due to the price effect. As prices are strategic complements the competitive contract price increases with increasing standard contract price. On the other hand, with one contract less, the demand for each of the other contracts is higher. Therefore, except for the standard contract, the competitive contract price could be set higher than in case of market entry. As without further specification it is unclear which of the two effects outweighs the other no clear-cut answer concerning the sign of the first term could be deduced. The second and the third term represent the revenue effect, the last term is the increase in costs due to the demand effect, which are all positive. Thus, if the demand-driven revenue effect is sufficiently high, the incumbent could be better off choosing a lower standard contract price. This can be one equilibrium solution in which the standard contract price is low enough to deter further market entry. Note that we do not model the market demand explicitly by introducing the elasticities and switching costs. Thus, further equilibrium solutions are possible.

In a nutshell, we have shown, first, that market entry could be affected by the price or the price-cost margin of the incumbent and, second, that it might be even profitable for the incumbent to use its standard contract strategically. 
Hypothesis: The price-cost margin or the price for the standard contract could affect the number of competitors in the market. Thus, the lower the price-cost margin the fewer competitors are in the market. $^{19}$

\section{Empirical Analysis}

In our econometric model we control for alternative impact factors on the standard contract price and also on the distribution charges. We have kept the theoretical model as simple as possible and assumed that each competitor offers only one contract. We relax this assumption in the empirical part of the paper and estimate along with the number of entrants, the number of competitive contracts. Exogenous variables are the absolute price-cost margin (or the markup), ${ }^{20} p_{s t}-d c$, of the standard contract as well as additional instruments and control variables. According to our model the markup would determine the number of contracts or competitors. Due to lack of variables, such as firms' demand or costs we are not able to identify how an incumbent uses its standard contract price to influence competition by using a structural form derived by our theoretical model. ${ }^{21}$ Therefore, we apply a reduced form model to analyze whether the price markup affects the number of contracts and competitors or does not. If we find an effect statistically different from zero it means that incumbent providers are in a position where they can affect competition in terms of the number of competitors (or contracts) in the market.

As it has been frequently shown in the literature on entry barriers to an essential facility that the distribution charges might act as a foreclosure instrument, therefore we did not focus on distribution charge regulation in our theoretical model. Nevertheless, we take distribution charges into account in the econometric analysis since these are regulated on a cost basis that in turn might be influenced by grid owners. As we observe huge variations between distribution charges among the market areas, we are in particular interested in network and market characteristics which influence operators' costs and, thus, determine the distribution charges.

\subsection{Econometric Model}

Distribution charges are two-part tariffs which consist of a fixed fee for serving a particular customer and a variable fee for the quantity of electricity transmitted to a household. For firms that offer differentiated contracts the marginal costs remain nearly the same as long as the wholesale electricity price is unaffected by the downstream contracts. If that is not necessarily the case, suppliers can hedge their risks by trading future contracts. Thus, purchasing costs for electricity should not be affected by the contract terms. If our assumptions are applicable, we should observe a higher number of contracts (per firm) in markets with a higher standard contract price-distribution charge margin since differentiation allows for increasing profits due to heterogeneous customer characteristics and relaxed price competition. The higher the markup the more contracts can be offered. In contrast, a low markup cannot accommodate more variation in contracts and prices as the standard contract price is considered to be the highest in the market. We analyze both the impact of the incumbents'

\footnotetext{
${ }^{19}$ We analyse also the impact of the price-cost margin on the number of contracts offered in the market and the average number of contracts per provider as an indicator for product differentiation.

${ }^{20}$ We observe the distribution charges, which varies across the distinct markets. However, we have no data on marginal costs for electricity.

${ }^{21}$ To account for firm heterogeneity, for example in costs, we introduced firm dummies. The results of the estimation, however, remained unaffected (see also footnote 14).
} 
behavior on the number of providers and on the number of offered contracts with prices below the standard contract price to see whether additional idiosyncratic elements in the decision to enter a market and to offer an additional contract exist.

A competitors' decision to enter a particular (sub) market is not only driven by the strategic behavior of the incumbent but should also be affected by cost-related aspects (with regard to both prices and distribution charges) and customer characteristics (with regard to prices). As with most of empirical literature on market entry that use cross-section data, we assume that a market can accommodate a certain number of entrants. ${ }^{22}$ This is the equilibrium number of competitors that given the equilibrium price and demand can enter without incur any losses. As discussed in detail in section 3 the suppliers' behavior might be driven by the customers' price-sensitivity, procurement and production costs and by the strategic interaction of competitors. Thus, we formulate the market supply equation as follows:

$$
y_{i}=f\left(\text { markup }_{i}, d c_{i}, \text { customers }_{i}\right)
$$

where $y_{i}$ stands for a) the number of providers, b) the number of contracts with prices below the standard contract price for each region and c) the number of contracts per provider with prices below the standard contract price. markup $_{i}$ is the difference between the standard contract price charged by the incumbent in market $i$ and the distribution charge in this market:

$$
\operatorname{markup}_{i}=p_{i}^{s t}-d c_{i}
$$

customers $_{i}$ is a vector of customer characteristics. These customer characteristics are control variables which are dedicated to regional aspects like the number of multi-apartment houses or average household size. All variables are based on the zip-code area $i$ as price information is available on this aggregation level.

We break down the markup into two explanatory equations::

$$
\begin{aligned}
& p_{i}^{s t}=g\left(\text { customers }_{i}, d c_{i}\right) \\
& d c_{i}=h\left(\text { grid }_{i}\right)
\end{aligned}
$$

The price of the standard contract is explained by customer characteristics and market characteristics, for example market density, and market specific distribution charges. As distribution charges are cot-based regulated, grid characteristics, grid $_{i}$, such as grid length, meter points or grid losses, are employed meter points to proxy the grid costs $c_{\text {grid }}$. For the empirical implementation of the equation system 9 to 12 we assume the following log-log structure:

$$
\begin{aligned}
& \log \left(y_{i}\right)=\alpha_{1}+\beta_{\text {markup }}{ }^{1} \log \left(\text { markup }_{i}\right)+\beta_{d c}{ }^{1} \log \left(d c_{i}\right)+\text { customers }_{i}{ }^{\prime} \beta_{\text {cust }}{ }^{1}+\varepsilon_{1} \\
& \log \left(p_{i}^{\text {st }}\right)=\alpha_{2}+\text { customers }_{i}{ }^{\prime} \beta_{\text {cust }}{ }^{2}+\text { grid }_{i}{ }^{\prime} \beta_{\text {grid }}{ }^{2}+\varepsilon_{2} \\
& \log \left(d c_{i}\right)=\alpha_{3}+\text { grid }_{i}{ }^{\prime} \beta_{\text {grid }}{ }^{3}+\varepsilon_{3}
\end{aligned}
$$

\footnotetext{
${ }^{22}$ For example, Bresnahan and Reiss (1990), Berry and Valdfogel (1999), Abraham et al. (2007), and Ferrari and Verboven (2010).
} 
$\alpha$ 's represent fixed effects while $\beta$ 's are coefficient vectors of the variables in the equations. $\log \left(\right.$ markup $\left._{i}\right)$ and $\log \left(d c_{i}\right)$ in the first equation are constructed using the procedure proposed in Zellner and Theil (1962) where $\log \left(\right.$ markup $\left._{i}\right)$ is the difference of the standard contract price equation and the distribution charge equation. $\log \left(d c_{i}\right)$ is instrumented using the distribution charge equation only.

Distribution charges and, expectedly, standard contract prices are cost-oriented and thus differ among local markets. It is thus inevitable to use a measure which is comparable across multiple regions. The log-log specification excludes level effects which might stem from other regional influences not covered by other control variables.

$\beta_{\text {markup }}$ and $\beta_{d c}$ represent the influence of strategic variables. If we find $\beta_{\text {markup }}$ being significantly positive we know that the markup of the standard contract positively affects the number of entrants and contracts (which corresponds to the hypothesis), i.e. the higher the standard contract price over the distribution charge the more contracts or providers are active in a market. If we additionally find $\beta_{d c}$ being significantly negative, distribution charges could also be used as an instrument for blocking entry as commonly mentioned in the literature (see e.g. Laffont and Tirole (2000)). Note that distribution charges are cost-based regulated. Price sensitivity could only be proxied through the coefficients of the customer characteristics. For our analysis we have employed alternative variables like purchasing power, share of multi-apartment houses and the fluctuation rate as the sum of households moving to and from a region. Price-sensitivity is expected to be higher when purchasing power is lower, and the higher the share of multi-apartment houses the higher the fluctuation rate.

As we assume the competition equation depending on the other two equations, we estimate the equations simultaneously employing 3SLS approach, where we constrain the price difference in the competition equations as described above. Using this estimation method we allow for correlation between the error terms among the equations as we assume that there exist certain market characteristics or shocks which affect all endogenous variables in the equations system.

\subsection{Data Selection}

We employ data from multiple sources which provide information on offered contracts, grid characteristics and customer characteristics at the zip code level and which represents a cross-sectional dataset as of September 2008. Data on household contracts were obtained from the online price comparison platform Verivox, where customers who are willing to switch their supplier can compare the contracts offered by competitors. ${ }^{23}$ Our cross-sectional data include all contracts offered by a particular provider with all contract conditions, for example tariffs (mainly two-part tariffs) and bonuses provided via the Verivox platform. Data on distribution network characteristics, for example, distribution areas, meter points and distribution charges are obtained from E'net, an information service provider specialized in energy markets. As we have no contract-specific demand data, we use information on customer characteristics on a regional level provided by Acxiom. The comprehensive dataset includes household size and status information, area and building characteristics and other socio-regional information which is calculated on a zip code level based on publicly available and private statistics.

\footnotetext{
${ }^{23}$ www.verivox.de, Verivox is the most established electricity comparison platform for all zip code regions in Germany.
} 
In our study, the relevant geographic market equals the zip code area since entrants choose specific zip-code areas where they place their offer. In contrast, in case of market investigations according to German Competition Authority the geographical delineation equals the area supplied by one distribution network operator. As the zip code area does not necessarily equal the distribution area of one operator, we deviate from this market definition for empirical purposes because we observe market entries only in particular zip codes. Suppose that a network operator distributes the electricity in two zip codes 1 and 2. These zip codes are totally different in their market characteristics so that due to expected profits a firm decides to enter only in one zip code 1 but not in zip code 2. A problem occurs in cases where we observe two network operators in only one zip code. We omitted these zip codes in our empirical analyses to avoid assumptions on market characteristics at lower level than zip-codes. ${ }^{24}$ Note that we are not interested on firms' individual pattern of entry but on the number of the entrants in a certain zip-code area.

\subsection{Data Description}

Table 1 provides an overview of the variables used in the econometric model. The last three columns indicate which equations the variables enter and which effect is expected either from empirical findings in the literature or from a theoretical point of view and from the findings of our model presented above. The dependent variable in the supply equation is the number of providers, the number of contracts offered at a price below the standard contract price or the number of contracts per provider offered at a price below the standard contract price. The standard contract price is the total per year price which has to be paid by a representative one-, two- or three-and-more-person household in this type of incumbent contract. To construct the distribution charge variable we sum up the fixed elements (monthly fixed fee, metering fee) and add the quantity dependent element times the average consumption level $(1500 \mathrm{kWh}$ for one-person households, $2800 \mathrm{kWh}$ for twoperson households and $4000 \mathrm{kWh}$ for more-than-two-person households).

We expect a negative effect of the distribution charges on the number of competitors and a positive effect on standard contract price. Additionally, we expect a positive effect of the markup on the dependent variables in the supply equations as explained by the theoretical model. While we did not differentiate providers from contracts in the theoretical part, we expect the markup effect on providers to be lower as the decision to enter a market is driven by more extensive start-up expenditures and, thus, by fewer impacts of short-run related aspects than the decision to offer an additional contract.

We expect a positive impact of purchasing power on both the supply and the standard contract price equations because a higher purchasing power allows for higher prices and more product differentiation and consequently makes a region more attractive for competitors.

\footnotetext{
${ }^{24}$ Although demand characteristics are entirely independent among zip-code areas, there might be factors that are correlated between zip-code areas that are located within a relevant market supplied by one incumbent (distribution network operator). For example, the distribution charges are the same for all entrants independent in which zip-code area they entered as long as the zip-code areas are located within the relevant market. Factors that we do not observe are captured in the error terms of our equations. However, the error terms are assumed to be i.i.d.. As a relevant market is served by only one incumbent, introducing incumbent dummies to capture firm heterogeneity (as stated in footnote 14) we also capture the factors that are common for all zip-code area within the relevant market.
} 
In contrast, our expectations concerning the share of houses with more than one apartment are ambiguous: We expect a negative impact on distribution costs since in areas with high density less access lines have to be installed. The fluctuation rate is the share of households per total households which have moved into the zip code area or left it during the last year. We use this measure as a proxy for movements across the borders of the distribution area as we do not have information on this aggregation level. Since customers who want to be served by a contract other than the standard contract have to announce their choice about six to eight weeks before they move, we expect many households with switching intentions to switch after they have moved. Consequently, with a high fluctuation rate the (short-run) demand for a standard contract could be higher. Moreover, in regions with a higher fluctuation rate (e.g. around universities) we expect customers to be more flexible which might also affect their intention to switch to alternative contracts making these regions more attractive for competitors. 
Table 1: Variables of the empirical model

\begin{tabular}{|c|c|c|c|c|}
\hline Dependent Variables & & & & \\
\hline \# providers & Number of providers & \multirow{3}{*}{\multicolumn{3}{|c|}{$\begin{array}{l}\text { Supply Function } \\
\text { Equations }\end{array}$}} \\
\hline $\begin{array}{l}\text { \# contracts below stand- } \\
\text { ard contracts }\end{array}$ & $\begin{array}{l}\text { Number of contracts with prices below the standard } \\
\text { contract price }\end{array}$ & & & \\
\hline \# contracts/provider & Number of contracts per provider & & & \\
\hline standard contract price & Standard contract price & \multicolumn{3}{|c|}{$\begin{array}{l}\text { Standard contract } \\
\text { price equation }\end{array}$} \\
\hline distribution charge & $\begin{array}{l}\text { Distribution charge to pay for supplying household } \\
\text { consumers }\end{array}$ & \multicolumn{3}{|c|}{$\begin{array}{l}\text { Distribution charge } \\
\text { equation }\end{array}$} \\
\hline Independent Variables & & 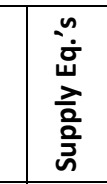 & 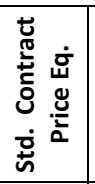 & 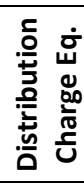 \\
\hline Markup & $\begin{array}{l}\text { Markup of standard contract price over distribution } \\
\text { charge }\end{array}$ & + & & \\
\hline \multicolumn{5}{|l|}{ Customer Characteristics } \\
\hline $\begin{array}{l}\text { purchasing power/ } \\
\text { household }\end{array}$ & $\begin{array}{l}\text { Purchasing power of households (single, double, fami- } \\
\text { ly) }\end{array}$ & + & + & \\
\hline $\begin{array}{l}\text { share apartment build- } \\
\text { ings }\end{array}$ & $\begin{array}{l}\text { Share of houses with more than } 1 \text { apartment in a } \\
\text { region }\end{array}$ & - & - & - \\
\hline fluctuation rate & $\begin{array}{l}\text { Fluctuation rate (share of households moving to a } \\
\text { region and leaving a region per total households) }\end{array}$ & $+/-$ & + & \\
\hline \multicolumn{5}{|l|}{ Grid Characteristics } \\
\hline distribution area (Iv) & Distribution area of low voltage grid (sq. km) & + & + & + \\
\hline $\begin{array}{l}\text { distribution area } \\
\text { (Iv)/area }\end{array}$ & Share distribution area of low voltage grid & + & $+/-$ & - \\
\hline share cable & $\begin{array}{l}\text { Share of low voltage cable grid length per total low } \\
\text { voltage distribution grid length (also including over- } \\
\text { head lines) }\end{array}$ & & - & - \\
\hline \# meter points Iv & Number of meter points in low voltage grid & & - & - \\
\hline \multicolumn{5}{|l|}{ High Voltage Zones } \\
\hline hv zone Vattenfall & High voltage zone of Vattenfall & & & \\
\hline hv zone E.On & High voltage zone of E.ON & & & \\
\hline hv zone RWE & High voltage zone of RWE & & & \\
\hline hv zone EnBW & High voltage zone of EnBW & & & \\
\hline
\end{tabular}

Concerning grid characteristics we expect a positive impact from the total size of the distribution area on all dependent variables. With regard to the share of distribution area per total area we expect similar results as for population density. However, we use the grid-based measure instead of population density as supply areas are mostly larger than zip code regions. As distribution charges are paid for grid access, using zip code regions-related measures might result in deterred coefficients. Similar to Salies (2008) and Salies and Waddams Price (2004), we anticipate a scope effect of underground lines since maintenance costs for cable lines are lower. Finally, we expect a negative 
effect of the number of meter points on distribution charges because the problem of voltage fluctuation on the distribution level could be reduced with more points.

We have selected information for three alternative user groups which are $1500 \mathrm{kWh}, 2800 \mathrm{kWh}$ and $4000 \mathrm{kWh}$ per year since these usage levels are average consumption levels for one-, two- and more-than-two person households in Germany. ${ }^{25}$ Prices are average total prices per usage group per year since not the technical composition of prices but only the total price to pay is relevant for customers since the annual electricity usage is (at least in the short run) constant. ${ }^{26}$ Customer information is selected per household (not per person). Summary statistics for the alternative customer groups are presented in table 3 in the appendix.

Table 2 provides a short summary of the competition variables used in the analysis. Values are means per usage group across all zip-code areas. While the total number of contracts is highest for one-person households and decreases for family households, the number of contracts with prices below the standard contract price is lowest for one-person households but highest for two-person households. While the number of providers remains constant for all user groups, more contracts with prices below the standard contract price are offered to two-persons-households. In contrast, we observe that the absolute (and also the relative) markup of standard contract prices above distribution charges increases from the $1500 \mathrm{kWh}$ to the $4000 \mathrm{kWh}$ contract. In particular for energy distribution scale effects seem to exist (see also Salies, 2008) which are not passed on to customers.

Table 2: Means of competition variables

\begin{tabular}{|l|c|c|c|}
\hline & $\mathbf{1 5 0 0} \mathbf{~ k W h}$ & $\mathbf{2 8 0 0} \mathbf{~ W W h}$ & $\mathbf{4 0 0 0} \mathbf{~ W W h}$ \\
\hline \# contr. below standard contract & 88.4 & 92.5 & 91.3 \\
\hline \# providers & 46.1 & 46.1 & 46.1 \\
\hline standard contract price (in euro) & 385.9 & 644.4 & 882.9 \\
\hline $\begin{array}{l}\text { incumbent's lowest price contract } \\
\text { (in euro) }\end{array}$ & 357.9 & 605.2 & 831.2 \\
\hline $\begin{array}{l}\text { total lowest price contract lowest } \\
\text { price (in euro) }\end{array}$ & 286.2 & 524.7 & 706.8 \\
\hline Markup (in euro) & 282.7 & 481.2 & 664.3 \\
\hline
\end{tabular}

Comparing the incumbents' competitive contract prices with those of the low price contracts of competitors we find incumbents' competitive prices to be only between 6.0 and 7.4 percent below the standard contract price whereas the lowest competitor's price is 18.5 to 26.7 percent below the standard contract price. Taking into account that less than 7 percent of all households have switched to an alternative provider but about 34 percent have switched to an alternative incumbent's contract these figures point to a high market power of the incumbent providers. The findings in Salies and Waddams Price (2004) also support these results of the impact of demand shares on prices.

\footnotetext{
${ }^{25}$ We have compared average consumption levels from multiple sources, i.e. providers, associations and information portals who all offer similar recommendations and used the levels proposed by Verivox.

${ }^{26}$ We focus on annual prices and ignore contract characteristics, such as electricity mix or prepayment.
} 
Note that we exclude those zip-code areas for the econometrical analysis where more than one grid owner is active. These regions are crossover areas between alternative grids.

\section{Estimation Results and Discussion}

Estimation results are provided in table 4 in the appendix. The first three columns show the results of the analysis when using the number of contracts with prices below the incumbent's standard contract as a dependent variable in the supply equation. Columns 3 to 6 represent the results with the number of providers offering at least one contract in a region as a dependent variable. Finally, the last three columns show the estimation results of the ratio of the number of contracts to the number of providers ratio as the dependent variable. ${ }^{27,28}$

Concerning the outcomes of the theoretical model and the expectations from the descriptive discussion we find mixed results: The coefficients for markup show the expected results only for the number of contracts. For the provider equations, however, they are ambiguous. The absolute markup coefficients are much lower for the provider equations and even insignificant for the 2800 $\mathrm{kWh}$ equation whereas the introduction of an additional contract is significantly affected by the markup. We interpret this result as an increasing scope for price discrimination. Higher markup allows the competitors to extend discrimination (and offer more contracts) and at the same time undercut the standard contract price.

As the incumbents use two-part tariffs it possible to target certain customer groups with different consumption levels, since a two-part tariff itself is an instrument for price discrimination. While the coefficient for $2800 \mathrm{kWh}$ is statistically not significant, we confirm our hypothesis for $1500 \mathrm{kWh}$ (one-person household). The lower the markup the lower is the number of competitors. Thus, setting a lower standard price for this customer group the incumbent can prevent market entry e.g. prevent competitors from offering attractive contracts to this group. The fact why this can happen is caused by switching behavior of customers that depend on their total consumption. According to the German Regulation Authority customers with high consumption are more likely to switch their supplier compared with customers with lower consumption (Bundesnetzagentur, 2010). The rationale is that the absolute savings increase with consumption whereas the absolute switching costs are likely to be nearly the same, i.e., the relative switching costs are lower for big households compared with small households. Therefore, the outcome of the theoretical model may apply as lower price for standard contract prevent customers' switching, so that the revenue driven effects are positive, and at the same time the lower price prevents market entry in this market segment. For some competitors, however, the low consumption group is not profitable, i.e. the expected profits from market entry are negative.

We observe the opposite scenario for big households with high consumption (4000 kWh). In this market segment entry is still profitable for competitors although the markup might be low. Usually incumbents offer additional competitive contracts for customers who are willing to switch the supplier. These are low priced contracts that have high cross-price effects with competitors' prices. In

\footnotetext{
${ }^{27}$ As the large number of highly significant coefficients might be caused by potential overidentification problems due to the fact that our analysis is based on zip code level we conducted Hansen tests for overidentification, but the results reject the hypothesis of overidentification for our dataset.

${ }^{28}$ We mainly compare our findings with the results of Salies and Waddams Price (2004) and Salies (2008) as these papers are, to the best of our knowledge, most closely related to our models.
} 
contrast to the case above, where the low consumption customers remain with the standard contract, the high consumption customers are likely to actively participate in supplier switching. This results in price discrimination between active and passive market participants as the price difference between "active" and "passive" customers can rise. Therefore, the profitability of market entry depends mainly on the incumbents' competitive prices for "active" customers.

Combining these findings with the significant results for distribution charge coefficient brings us to the following explanation: Following the literature on entry barriers access prices to an essential facility, the distribution charges, could be used as an instrument to foreclose providers, as, ceteris paribus, higher levels of distribution charges hinder a long-run oriented engagement of providers in a competitive market (see e.g. Laffont and Tirole, 2000). Thus, the increase of distribution charges is similar to the raise of downstream providers' costs (see e.g. Salop and Scheffman, 1983). These results show the importance of effective regulation regimes. In particular vertically integrated network operators have an incentive to discriminate against competitors. Thus, regulation has to prevent artificial cost movements between downstream and upstream (network). Tough regulation is also required in a price- (or revenue-) cap regulation regime for strategic access pricing in different markets, such as household or business customers that aim at preventing market entry (Riechmann,2000). For example, in markets with (expected) lower competition intensity, charges might be lower than in markets which allow more competition and at same time are profitable for the incumbent. Higher charges could prevent entry or raise the competitors' costs and create an advantage the retail incumbent. In that case the network can even cross-subsidize the low access charge in one market with higher charges in other markets as long as revenue-cap requirements are met.

Salies (2008) extensively discusses the effect of regional factors on prices. While he finds a significant negative effect of customer density in particular for smaller usage groups the impact of this measure loses significance in the case of higher energy consumption. Using distribution area per total area we find a negative effect of the related coefficients both in the standard contract price and distribution charge equations which corresponds to the results in the UK market and which might be due to the fact that the installation and maintenance of a distribution grid is more expensive in less covered regions. With regard to the total size of the distribution area we find a positive effect on distribution costs particularly for the contract equations since the transmission costs also increase with the total grid length. Concerning the share of underground cables we find a significant negative coefficient which in our opinion is mainly driven by lower maintenance costs and a lower impact of atmospheric conditions on underground circuits. We also observe a negative impact of the number of meter points. As already mentioned above, with a higher number of meter points voltage fluctuations on the total distribution grid might be reduced and thus lead to lower distribution costs.

The share of apartment buildings in a particular region consists of a cost and a demand component. First, scale effects with regard to energy provision might exist as households in apartment buildings can be served by one common distribution cable. Additionally, apartment buildings are mainly constructed in more densely populated areas. Salies' (2008) scale effect argument is thus also supported by our estimations. Second, as the income of households living in apartment buildings is probably lower than the income of households living in single-family houses electricity prices are of more relevance for these customers what raises low-price offers in these regions. 
Additionally, we find that the higher the average purchasing power per household the lower the number of competitors in the relevant region. Concerning the fluctuation rate a highly significant positive impact on standard contract

Figure 4: Number of providers per zip code area

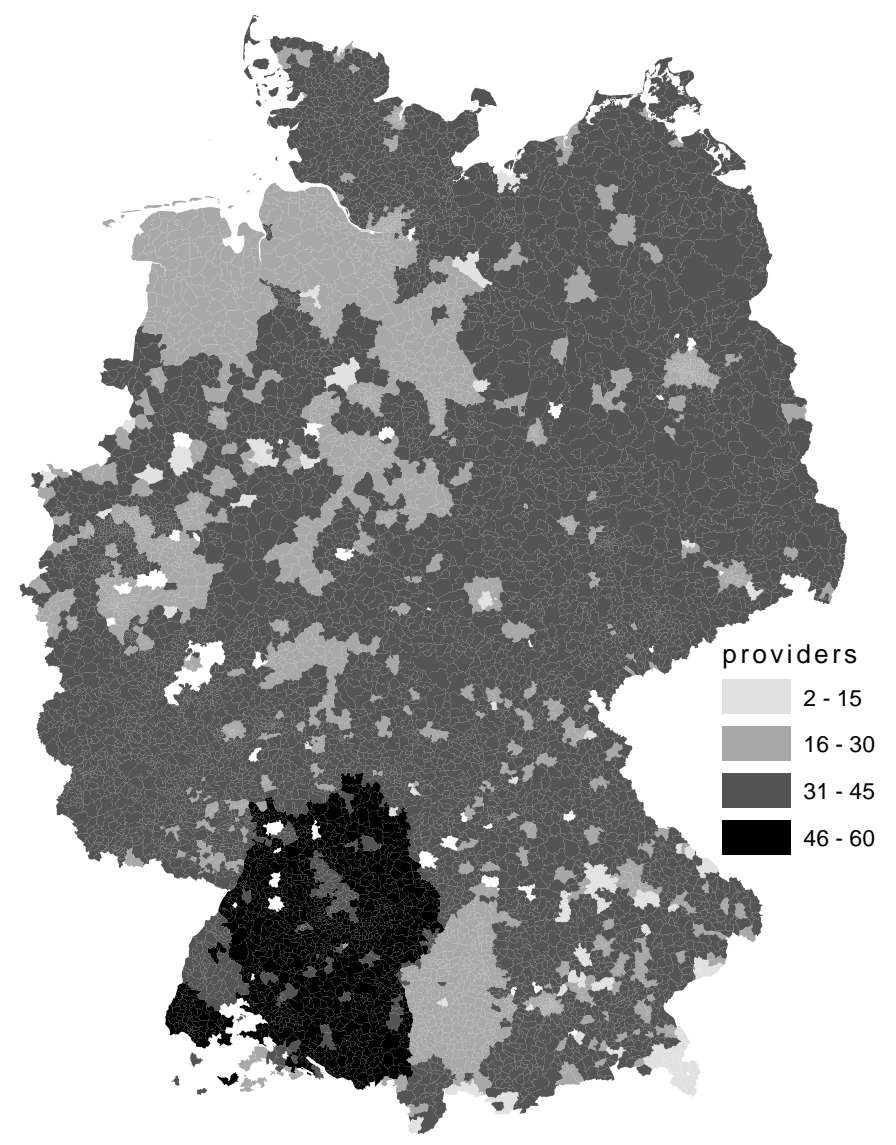

Figure 5: Number of contracts per zip code area 


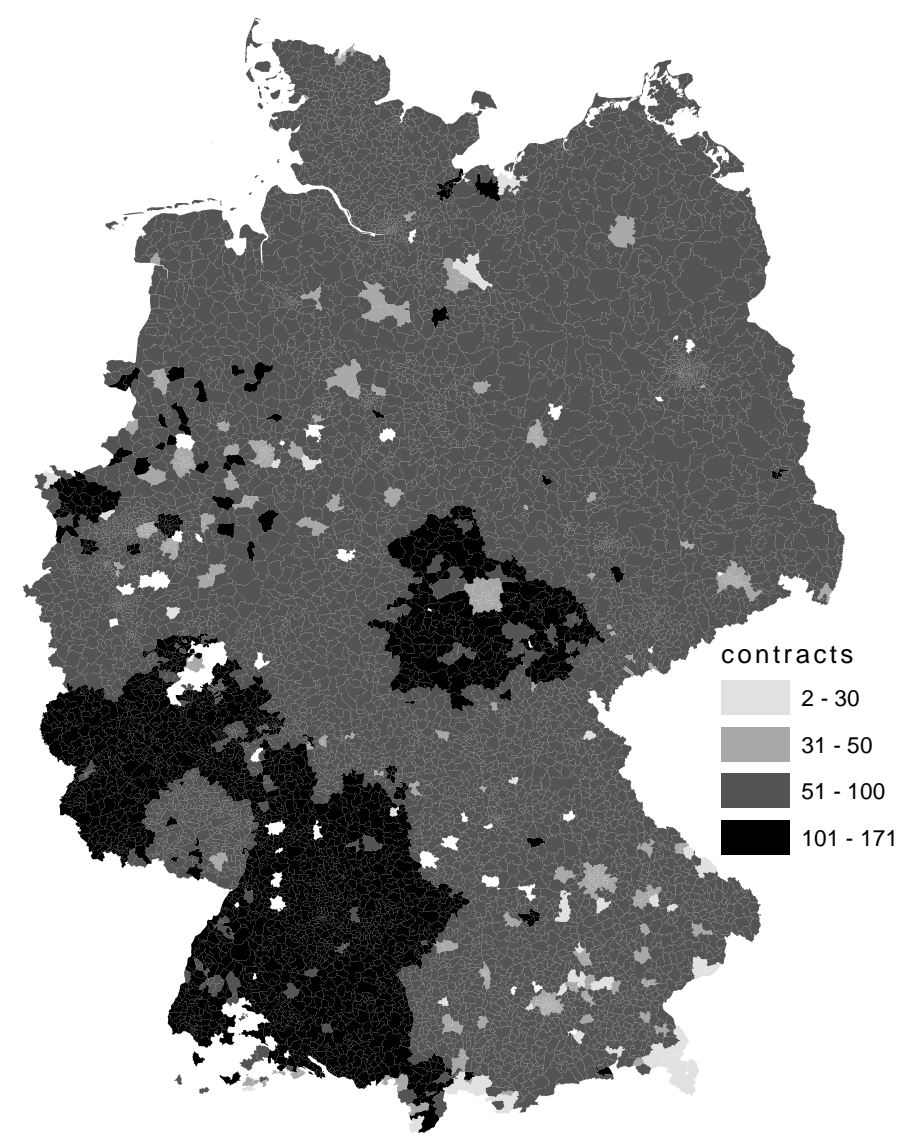

prices is deduced. As described above, switching from a standard contract lasts about six to eight weeks. Moving households, therefore, switch to an alternative provider after they have moved and mostly ignore the opportunity beforehand. Thus, the data support the argument that there might be an advantage for the standard contract providers particularly in regions with a higher fluctuation rate.

Concerning differences between high voltage areas as drivers for price and competition differences, significantly more providers and contracts exist in the EnBW area which is the smallest of the four high voltage areas in Germany. Taking a look at the effect on standard contract prices we find that they are also significantly higher in the EnBW area. In contrast, distribution charges are lower in the EnBW area in comparison to the three other areas. In summary, these findings support the hypothesis of a positive interrelation of the markup of standard contract prices over distribution charges with the number of competitors. Figures 4 and 5 provide graphical evidence for these results. The more shaded the region the higher the number of providers (Figure 4) or contracts (Figure $5) .{ }^{29}$

In a nutshell, distribution charges are found to affect the number of competitors and the number of contracts. However, providers, for which distribution charges are no entry barrier, offer significantly more alternative contracts the higher the distribution charges. With regard to the markup of standard contract prices over distribution charges we find significantly positive effects on the number of contracts but not on the number of providers in a big household segment. Solely for one-

\footnotetext{
${ }^{29}$ Besides regional aspects there might be also ownership aspects which drive standard contract price differences among regions. As this interrelation is of particular interest for European markets with many public (local) owners and public private partnership relations we address the aspect of vertical integration and ownership with incumbents' contract offers in subsequent companion study.
} 
person household small consumption, we cannot reject our hypothesis as the number of entrants decreases with decreasing standard contract price. In contrast to big households, small households are likely to be "passive" and remain with standard contract, thus, it could be profitable for the incumbent to lower the standard contract price to prevent switching and profitable market entry in this segment. Due to two-part tariffs it is possible to target specific customer groups, so that the standard contract price takes into account the relative high switching costs whereas the competitive contract price mainly accounts for competitors' prices. Thus, the intense the competition the higher the price dispersion paid by "passive" and "active" customers per $\mathrm{kWh} .{ }^{30}$ In our opinion, to increase competition it is required to further decrease switching costs and reduce information asymmetries across customers for alternative contracts. This might help to reduce the share of "passive" customers and at the same time reduce the prices due to increased competition.

\section{Conclusions}

The electricity distribution grid access is known to be a target of regulation since this part of the electricity grid is a natural monopoly which should not be duplicated. Instead, it should be opened for all electricity suppliers to reach potential customers at a regulated access price. What is not in the focus of regulation are the retail prices. All "non-switchers" are served by the so called standard contract offered by former monopolists. As these customers seem to be highly price-insensitive these contracts are high-price contracts compared to other contracts in the market.

We show in a theoretical model that the standard contract price level can affect the entry decision of potential competitors in retail electricity markets. In the benchmark case where market entry occurs and the incumbent then competes, it asks for higher standard contract prices and higher competitive contract prices than competitors. With a lower standard contract price, customers are less willing to switch and, additionally, it becomes more difficult for competitors to undercut the standard contract price. We have shown that under particular demand conditions depending on price elasticity this pricing strategy could be profitable for the incumbent.

We test the theoretical findings employing data for German retail electricity competition for three different consumption levels (one-, two- and four-person households) which differ in their relative switching costs and the likelihood of switching suppliers. While doing so, we separate effects on distribution charges from those that apply to pricing decisions and those which are relevant for both. We find that the markup of standard contract price over distribution charges has a significantly positive effect mainly on the number of contracts. In contrast, the effect on the number of providers is ambiguous. For a customer group (one-person households), which compared to other groups have the highest relative switching costs, we could confirm our theoretical findings. Thus, the number of competitors is lower in markets in which the markup for the standard contract is low. Obviously in this case further market entry is not profitable. In contrast, for other customer groups we have to reject our hypothesis that lower markup prevents market entry. These results show that the incumbents' try to divide the market into different segments and engage in price discrimination. Two-part tariffs allow the incumbents to target specific groups, meaning standard contracts for lower consumption levels and competitive contract for higher consumption levels. With its standard

\footnotetext{
${ }^{30}$ This finding confirms the theoretical results derived by Varian (1980).
} 
contract pricing the incumbent can prevent market entry in low consumption segment. To increase competition also for this customer group instruments have to be implemented that reduce switching costs, especially in case of vertically integrated incumbents, and reduce information asymmetries across customers for offered alternative contracts.

Tough regulation for vertically integrated incumbents is required as our results show that distribution charges have a negative impact on competition in terms of the number of competitors. Various theoretical studies show that an integrated network provider has the incentive to raise rivals costs. Although the network access charges are regulated there might be strategic choices among different markets, such as for household, business or industry customers, particularly in a revenue-cap regime. Therefore, chances for discrimination among different markets need to be taken into account when implementing regulation regimes. Furthermore, recent studies show that non-price discrimination (for example Höffler and Kranz, 2011) could be also an issue that does not only affect rivals' costs but also raises the switching costs for customers, e.g. by delaying the switching process. 


\section{References}

Abraham, J. M.; Gaynor, M.; Vogt, W., B., 2007. Entry and Competition in Local Hospital Markets. The Journal of Industrial Economics. 55 (2), 265-288.

Bain, J.S., 1949. A Note on Pricing in Monopoly and Oligopoly. American Economic Review 39 (2), 448-464.

Berry, S. T.; Waldfogel, J., 1999. Free entry and social inefficiency in radio broadcasting. RAND Journal of Economics. 30 (3), 397-420.

Bresnahan, T., F; Reiss, P., C. , 1990. Entry in Monopoly Markets. Review of Economic Studies. 57 (4), 531-53.

Dixit, A., 1979. A Model of Duopoly Suggesting a Theory of Entry Barriers. Bell Journal of Economics 10 (1), 20-32.

Dixit, A., 1980. The Role of Investment in Entry-Deterrence. Economic Journal 90 (357), 95-106.

Farrell, J., 1985. Competition with Lock-in. GTE Laboratories Working Paper.

Farrell, J., Shapiro, C., 1988. Dynamic Competition with Switching Costs. RAND Journal of Economics 19 (1), 123-137.

Ferrari, S.; Verboven, F., 2010. Empirical analysis of markets with free and restricted entry. International Journal of Industrial Organization. 28 (4), 403-406.

Gaskins, D. W. Jr., 1970. Dynamic Limit Pricing: Optimal Pricing under Threat of Entry. Journal of Economic Theory 3, 306-322.

Gehrig, T.; Stenbacka, R., 2004. Differentiation-Induced Switching Costs and Poaching. Journal of Economics \& Management Strategy 13 (4), 635-55.

Höffler, F.; Kranz, S., 2011. Imperfect legal unbundling of monopolistic bottlenecks. Journal of Regulatory Economics. 39 (3), pp. 273-292.

Klemperer, P., 1987a. The Competitiveness of Markets with Switching Costs. RAND Journal of Economics 18 (1), 138-50.

Klemperer, P., 1987b. Entry Deterrence in Markets with Consumer Switching Costs. The Economic Journal 97, 99-117.

Klemperer, P., 1995. Competition when Consumers have Switching Costs: An Overview with Applications to Industrial Organization. Macroeconomics, and International Trade, Review of Economic Studies 62, 515-539.

Laffont, J. J., Tirole, J., 2000. Competition in Telecommunications. MIT Press.

Milgrom, P. R.; Roberts, J., 1982a. Limit Pricing and Entry Under Incomplete Information: An Equilibrium Analysis. Econometrica 50, 443-459. 
Milgrom, P.R.; Roberts, J., 1982b. Predation, Reputation and Entry Deterrence. Journal of Economic Theory 27, 280-312.

Monitoringbericht, 2008. Bundesnetzagentur für Elektrizität, Gas, Telekommunikation, Post und Eisenbahnen. http://www.bundesnetzagentur.de/media/archive/14513.pdf

Monitoringbericht, 2010. Bundesnetzagentur für Elektrizität, Gas, Telekommunikation, Post und Eisenbahnen.

http://www.bundesnetzagentur.de/SharedDocs/Downloads/DE/BNetzA/Presse/Berichte/2010/Monit oringbericht2010Energiepdf.pdf? blob=publicationFile

Rey, P., Tirole, J., 2003. A Primer on Foreclosure. Handbook of Industrial Organization III, NorthHolland publications.

Riechmann, C., 2000. Strategic pricing of grid access under partial price-caps -- electricity distribution in England and Wales. Energy Economics. 22 (2), pp. 187-207.

Salies, E., Waddams Price, C., 2004. Charges, Costs and Market Power: the Deregulated UK Electricity Retail Market. Working Paper, 1-24.

Salies, E., 2008. Mergers in the GB electricity market: effects on retail charges. Applied Economics 40 (11), 1483-90.

Salop, S. C.; Scheffman, D. T., 1983. Raising Rivals' Costs. American Economic Review 73(2), 267-271.

Schmalensee, R., 1981. Output and welfare implications of monopolistic third-degree price discrimination. American Economic Review 71, 242-47.

Shaffer, G.; Zhang, Z. J., 2000. Pay to Switch or Pay to Stay: Preference-Based Price Discrimination in Markets with Switching Costs. Journal of Economics \& Management Strategy 9 (3), 397424.

Spence, M., 1977. Entry, Capacity, Investment and Oligopolistic Pricing. Bell Journal of Economics 8 (2), 534-544.

Stiglitz, J. E., 1979. Equilibrium in Product Markets with Imperfect Information. American Economic Review 69 (2), 339-345.

Tirole, J., 2003. The Theory of Industrial Organization. The MIT Press, Cambridge (MA).

Varian, H. R.,1980. A Model of Sales. American Economic Review. 70 (4), 651.

Zellner, A.; Theil, H., 1962. Three-Stage Least Squares: Simultaneous Estimation of Simultaneous Equations. Econometrica 30 (1), 54-78. 


\section{Appendix}

\section{Data Overview and Estimation Results}

In the following we separately display results for the $1500 \mathrm{kWh}, 2800 \mathrm{kWh}$ and $4000 \mathrm{kWh}$ usage levels. A data overview is given in tables 3.

Tables 4 show the coefficients and standard errors for the three measures of competition both for the unadjusted (first three columns) and the mean-adjusted (second three columns) estimations. Standard errors are displayed in brackets. The dependent variable is displayed in the first line of each equation. Below the estimation results we have displayed the root mean squared error results (RMSE) for each estimation equation as a whole. The RMSE is a measure of the goodness of fit and the lower it is the lower the linear deviation between the estimate and the actual value.

Table 3a: Descriptive Statistics (average one-person households)

\begin{tabular}{|c|c|c|c|c|c|}
\hline $1500 \mathrm{kWh}$ & \# Obs. & Mean & Std. Dev. & Min & Max \\
\hline$\#$ contracts & 7899 & 237.8 & 33.2 & 32 & 341 \\
\hline \# contracts bel. standard contract & 7899 & 88.4 & 31.2 & 5 & 203 \\
\hline \# providers & 7899 & 46.1 & 6.167 & 13 & 62 \\
\hline standard contract price & 7899 & 385.9 & 18.4 & 291.6 & 459.3 \\
\hline low contract price & 7899 & 357.9 & 21.9 & 290.3 & 417.5 \\
\hline lowest price & 7899 & 286.2 & 11.2 & 220.5 & 351.0 \\
\hline price difference & 7915 & 282.7 & 18.7 & 198.2 & 334.0 \\
\hline purchasing power/single hh & 7893 & 41.5 & 44.8 & 0 & 290.0 \\
\hline fluctuation rate & 7891 & 0.106 & 0.050 & 0.002 & 1.738 \\
\hline share apartment buildings & 6514 & 0.365 & 0.169 & 0.051 & 0.939 \\
\hline distribution charge & 7915 & 103.3 & 12.4 & 69.7 & 149.6 \\
\hline distribution area (lv) & 7310 & 20.9 & 9.8 & 0.801 & 40.6 \\
\hline distribution area (lv)/area & 6350 & 0.459 & 0.170 & 0.161 & 1.009 \\
\hline share cable & 6225 & 0.693 & 0.102 & 0.300 & 0.975 \\
\hline$\#$ meter points $\mathrm{lv}$ & 7505 & 0.761 & 0.076 & 0.173 & 0.837 \\
\hline hv zone Vattenfall & 7833 & 0.208 & 0.406 & 0 & 1 \\
\hline hv zone E.On & 7833 & 0.429 & 0.495 & 0 & 1 \\
\hline hv zone RWE & 7833 & 0.239 & 0.426 & 0 & 1 \\
\hline hv zone EnBW & 7833 & 0.119 & 0.324 & 0 & 1 \\
\hline
\end{tabular}


Table 3b: Descriptive Statistics (average two-persons households)

\begin{tabular}{|c|c|c|c|c|c|}
\hline $2800 \mathrm{kWh}$ & \# Obs. & Mean & Std. Dev. & Min & Max \\
\hline \# contracts & 7912 & 183.4 & 33.4 & 32 & 276 \\
\hline \# contracts bel. standard contract & 7912 & 92.5 & 29.8 & 5 & 196 \\
\hline \# providers & 7912 & 46.1 & 6.165 & 13 & 62 \\
\hline std. contract price & 7912 & 644.4 & 28.8 & 542.2 & 807.8 \\
\hline low contract price & 7912 & 605.2 & 30.5 & 525.0 & 696.4 \\
\hline lowest price & 7912 & 524.7 & 7.984 & 393.6 & 574 \\
\hline price difference & 7906 & 481.2 & 26.7 & 389.5 & 604.9 \\
\hline purchasing power/double hh & 7907 & 69.4 & 67.3 & 0 & 581.6 \\
\hline fluctuation rate & 7904 & 0.106 & 0.050 & 0.002 & 1.738 \\
\hline share apartment buildings & 6505 & 0.365 & 0.169 & 0.051 & 0.939 \\
\hline distribution charge & 7906 & 163.2 & 19.4 & 113.6 & 230.6 \\
\hline distribution area (lv) & 7323 & 20.9 & 9.810 & 0.801 & 40.6 \\
\hline distribution area (lv)/area & 6363 & 0.459 & 0.170 & 0.161 & 1.009 \\
\hline share cable & 6216 & 0.693 & 0.102 & 0.300 & 0.975 \\
\hline$\#$ meter points $1 \mathrm{v}$ & 7518 & 0.761 & 0.076 & 0.173 & 0.837 \\
\hline hv zone Vattenfall & 7846 & 0.208 & 0.406 & 0 & 1 \\
\hline hv zone E.On & 7846 & 0.429 & 0.495 & 0 & 1 \\
\hline hv zone RWE & 7846 & 0.240 & 0.427 & 0 & 1 \\
\hline hv zone EnBW & 7846 & 0.119 & 0.324 & 0 & 1 \\
\hline
\end{tabular}


Table 3c: Descriptive Statistics (average three-and-more-persons households)

\begin{tabular}{|c|c|c|c|c|c|}
\hline $4000 \mathrm{kWh}$ & \# Obs. & Mean & Std. Dev. & Min & Max \\
\hline$\#$ contracts & 7899 & 173.7 & 30.3 & 32 & 276 \\
\hline \# contracts bel. standard contract & 7899 & 91.3 & 27.0 & 3 & 189 \\
\hline \# providers & 7899 & 46.1 & 6.167 & 13 & 62 \\
\hline standard contract price & 7899 & 882.9 & 40.7 & 728.5 & 1129.6 \\
\hline low contract price & 7899 & 831.2 & 39.6 & 680.0 & 959.4 \\
\hline lowest price & 7899 & 706.8 & 8.503 & 553.5 & 806.5 \\
\hline price difference & 7893 & 664.3 & 36.4 & 542.6 & 861.2 \\
\hline purchasing power/family hh & 7894 & 74.2 & 66.4 & 0 & 571.5 \\
\hline fluctuation rate & 7891 & 0.106 & 0.050 & 0.002 & 1.738 \\
\hline share apartment buildings & 6514 & 0.365 & 0.169 & 0.051 & 0.939 \\
\hline distribution area (lv) & 7310 & 20.9 & 9.8 & 0.801 & 40.6 \\
\hline distribution area (lv)/area & 6350 & 0.459 & 0.170 & 0.161 & 1.009 \\
\hline share cable & 7792 & 70.2 & 38.0 & 2.177 & 140.1 \\
\hline$\#$ meter points lv & 7505 & 0.761 & 0.076 & 0.173 & 0.837 \\
\hline hv zone Vattenfall & 7833 & 0.208 & 0.406 & 0 & 1 \\
\hline hv zone E.On & 7833 & 0.429 & 0.495 & 0 & 1 \\
\hline hv zone RWE & 7833 & 0.239 & 0.426 & 0 & 1 \\
\hline hv zone EnBW & 7833 & 0.119 & 0.324 & 0 & 1 \\
\hline distribution charge & 7893 & 218.6 & 26.5 & 154.0 & 310.4 \\
\hline
\end{tabular}


Table 4a: Competition Equation,

\begin{tabular}{|c|c|c|c|c|c|c|c|c|c|}
\hline \multirow[b]{2}{*}{$\mathrm{kWh}$} & \multicolumn{3}{|c|}{$\begin{array}{c}\log (\# \text { contracts below standard } \\
\text { contract })\end{array}$} & \multicolumn{3}{|c|}{$\log (\#$ providers $)$} & \multicolumn{3}{|c|}{$\begin{array}{c}\log (\# \text { contracts below standard } \\
\text { contract/providers })\end{array}$} \\
\hline & 1500 & 2800 & 4000 & 1500 & 2800 & 4000 & 1500 & 2800 & 4000 \\
\hline $\log ($ price diff $)$ & $\mid \begin{array}{l}2.581 * * * \\
(0.022)\end{array}$ & $\begin{array}{l}2.400 * * * \\
(0.026)\end{array}$ & $\begin{array}{l}2.276 * * * \\
(0.025)\end{array}$ & $\mid \begin{array}{l}0.170 * * * \\
(0.013)\end{array}$ & $\begin{array}{l}-0.012 \\
(0.015)\end{array}$ & $\begin{array}{l}-0.072 * * * \\
(0.014)\end{array}$ & $\mid \begin{array}{l}2.409 * * * \\
(0.016)\end{array}$ & $\begin{array}{l}2.412 * * * \\
(0.020)\end{array}$ & $\begin{array}{l}2.348 * * * \\
(0.019)\end{array}$ \\
\hline $\log ($ distribution charge $)$ & $\begin{array}{l}0.696 * * * \\
(0.034)\end{array}$ & $\begin{array}{l}0.326 * * * \\
(0.035)\end{array}$ & $\begin{array}{l}0.490 * * * \\
(0.034)\end{array}$ & $\begin{array}{l}-0.186 * * * \\
(0.021)\end{array}$ & $\begin{array}{l}-0.297 * * * \\
(0.020)\end{array}$ & $\begin{array}{l}-0.315 * * * \\
(0.020)\end{array}$ & $\begin{array}{l}0.882 * * * \\
(0.026)\end{array}$ & $\begin{array}{l}0.623 * * * \\
(0.026)\end{array}$ & $\begin{array}{l}0.805^{* * *} \\
(0.027)\end{array}$ \\
\hline distribution area $(1 \mathrm{v}) /$ area & $\begin{array}{l}-0.052 * * * \\
(0.013)\end{array}$ & $\begin{array}{l}-0.106 * * * \\
(0.013)\end{array}$ & $\begin{array}{l}-0.097 * * * \\
(0.013)\end{array}$ & $\begin{array}{l}-0.014 \\
(0.008)\end{array}$ & $\begin{array}{l}-0.032 * * * \\
(0.008)\end{array}$ & $\begin{array}{l}-0.035 * * * \\
(0.008)\end{array}$ & $\begin{array}{l}-0.037 * * * \\
(0.010)\end{array}$ & $\begin{array}{l}-0.074 * * * \\
(0.010)\end{array}$ & $\begin{array}{l}-0.062 * * * \\
(0.010)\end{array}$ \\
\hline $\begin{array}{l}\log \text { (purchasing power/ } \\
\text { hh size) }\end{array}$ & $\begin{array}{l}-0.030 * * * \\
(0.007)\end{array}$ & $\begin{array}{l}-0.118 * * * \\
(0.007)\end{array}$ & $\begin{array}{l}-0.058 * * * \\
(0.007)\end{array}$ & $\begin{array}{l}-0.101 * * * \\
(0.004)\end{array}$ & $\begin{array}{l}-0.111 * * * \\
(0.004)\end{array}$ & $\begin{array}{l}-0.108 * * * \\
(0.004)\end{array}$ & $\begin{array}{l}0.071 * * * \\
(0.005)\end{array}$ & $\begin{array}{l}-0.007 \\
(0.005)\end{array}$ & $\begin{array}{l}0.051 * * * \\
(0.005)\end{array}$ \\
\hline $\begin{array}{l}\text { share multi-apartment } \\
\text { houses }\end{array}$ & $\begin{array}{l}0.034 * * * \\
(0.004)\end{array}$ & $\begin{array}{l}0.013 * * * \\
(0.004)\end{array}$ & $\begin{array}{l}0.016 * * * \\
(0.004)\end{array}$ & $\begin{array}{l}0.017 * * * \\
(0.002)\end{array}$ & $\begin{array}{l}0.009 * * * \\
(0.002)\end{array}$ & $\begin{array}{l}0.005 * \\
(0.002)\end{array}$ & $\begin{array}{l}0.017 * * * \\
(0.003)\end{array}$ & $\begin{array}{l}0.004 \\
(0.003)\end{array}$ & $\begin{array}{l}0.011 * * * \\
(0.003)\end{array}$ \\
\hline fluctuation rate & $\begin{array}{l}-0.006 \\
(0.005)\end{array}$ & $\begin{array}{l}0.009 \\
(0.005)\end{array}$ & $\begin{array}{l}-0.005 \\
(0.005)\end{array}$ & $\begin{array}{l}-0.012 * * * \\
(0.003)\end{array}$ & $\begin{array}{l}-0.005 \\
(0.003)\end{array}$ & $\begin{array}{l}-0.002 \\
(0.003)\end{array}$ & $\begin{array}{l}0.006 \\
(0.003)\end{array}$ & $\begin{array}{l}0.014 * * * \\
(0.004)\end{array}$ & $\begin{array}{l}-0.002 \\
(0.004)\end{array}$ \\
\hline hv zone Vattenfall & $\begin{array}{l}0.684 * * * \\
(0.020)\end{array}$ & $\begin{array}{l}0.827 * * * \\
(0.021)\end{array}$ & $\begin{array}{l}0.767 * * * \\
(0.021)\end{array}$ & $\begin{array}{l}0.482 * * * \\
(0.012)\end{array}$ & $\begin{array}{l}0.509 * * * \\
(0.012)\end{array}$ & $\begin{array}{l}0.523 * * * \\
(0.012)\end{array}$ & $\begin{array}{l}0.201 * * * \\
(0.015)\end{array}$ & $\begin{array}{l}0.317 * * * \\
(0.016)\end{array}$ & $\begin{array}{l}0.244 * * * \\
(0.016)\end{array}$ \\
\hline hv zone E.On & $\begin{array}{l}0.864 * * * \\
(0.020)\end{array}$ & $\begin{array}{l}0.958 * * * \\
(0.021)\end{array}$ & $\begin{array}{l}0.970 * * * \\
(0.020)\end{array}$ & $\begin{array}{l}0.500 * * * \\
(0.012)\end{array}$ & $\begin{array}{l}0.486 * * * \\
(0.012)\end{array}$ & $\begin{array}{l}0.484 * * * \\
(0.012)\end{array}$ & $\begin{array}{l}0.363 * * * \\
(0.015)\end{array}$ & $\begin{array}{l}0.472 * * * \\
(0.016)\end{array}$ & $\begin{array}{l}0.486 * * * \\
(0.016)\end{array}$ \\
\hline hv zone RWE & $\begin{array}{l}0.846 * * * \\
(0.020)\end{array}$ & $\begin{array}{l}0.952 * * * \\
(0.021)\end{array}$ & $\begin{array}{l}0.992 * * * \\
(0.020)\end{array}$ & $\begin{array}{l}0.476 * * * \\
(0.012)\end{array}$ & $\begin{array}{l}0.494 * * * \\
(0.012)\end{array}$ & $\begin{array}{l}0.501 * * * \\
(0.012)\end{array}$ & $\begin{array}{l}0.370 * * * \\
(0.015)\end{array}$ & $\begin{array}{l}0.458 * * * \\
(0.016)\end{array}$ & $\begin{array}{l}0.492 * * * \\
(0.016)\end{array}$ \\
\hline hv zone EnBW & $\begin{array}{l}1.098 * * * \\
(0.021)\end{array}$ & $\begin{array}{l}1.201 * * * \\
(0.021)\end{array}$ & $\begin{array}{l}1.245^{* * *} \\
(0.021)\end{array}$ & $\begin{array}{l}0.687 * * * \\
(0.013)\end{array}$ & $\begin{array}{l}0.723 * * * \\
(0.012)\end{array}$ & $\begin{array}{l}0.740 * * * \\
(0.012)\end{array}$ & $\begin{array}{l}0.412 * * * \\
(0.015)\end{array}$ & $\begin{array}{l}0.478 * * * \\
(0.016)\end{array}$ & $\begin{array}{l}0.505 * * * \\
(0.017)\end{array}$ \\
\hline constant & $\begin{array}{l}-33.7 * * * \\
(0.470)\end{array}$ & $\begin{array}{l}-30.6 * * * \\
(0.509)\end{array}$ & $\begin{array}{l}-32.7 * * * \\
(0.487)\end{array}$ & $\begin{array}{l}3.227 * * * \\
(0.288)\end{array}$ & $\begin{array}{l}6.800 * * * \\
(0.294)\end{array}$ & $\begin{array}{l}7.997 * * * \\
(0.282)\end{array}$ & $\begin{array}{l}-36.9 * * * \\
(0.350)\end{array}$ & $\begin{array}{l}-37.4 * * * \\
(0.385)\end{array}$ & $\begin{array}{l}-40.7 * * * \\
(0.383)\end{array}$ \\
\hline
\end{tabular}


Table 4b: Standard Contract Price Equation (continued)

\begin{tabular}{|c|c|c|c|c|c|c|c|c|c|}
\hline \multirow[b]{2}{*}{$\mathrm{kWh}$} & \multicolumn{3}{|c|}{$\begin{array}{c}\log (\# \text { contracts below standard } \\
\text { contract })\end{array}$} & \multicolumn{3}{|c|}{$\log (\#$ providers $)$} & \multicolumn{3}{|c|}{$\begin{array}{c}\log (\# \text { contracts below standard } \\
\text { contract/providers })\end{array}$} \\
\hline & 1500 & 2800 & 4000 & 1500 & 2800 & 4000 & 1500 & 2800 & 4000 \\
\hline $\log$ (purchasing power/ & $-0.006 * * *$ & $-0.010 * * *$ & $-0.012 * * *$ & $-0.006 * * *$ & $-0.010 * * *$ & $-0.012 * * *$ & $-0.006 * * *$ & $-0.010 * * *$ & $-0.012 * * *$ \\
\hline hh size) & $(0.001)$ & $(0.001)$ & $(0.001)$ & $(0.001)$ & $(0.001)$ & $(0.001)$ & $(0.001)$ & $(0.001)$ & $(0.001)$ \\
\hline share multi-apartment & $-0.027 * * *$ & $-0.026^{* * * *}$ & $-0.022 * * *$ & $-0.030 * * *$ & $-0.027 * * *$ & $-0.026 * * *$ & $-0.028 * * *$ & $-0.025 * * *$ & $-0.023 * * *$ \\
\hline houses & $(0.004)$ & $(0.003)$ & $(0.003)$ & $(0.004)$ & $(0.003)$ & $(0.003)$ & $(0.004)$ & $(0.003)$ & $(0.003)$ \\
\hline fluctuation rate & $\begin{array}{l}0.006 * * * \\
(0.001)\end{array}$ & $\begin{array}{l}0.008 * * * \\
(0.001)\end{array}$ & $\begin{array}{l}0.009 * * * \\
(0.001)\end{array}$ & $\begin{array}{l}0.006 * * * \\
(0.001)\end{array}$ & $\begin{array}{l}0.008 * * * \\
(0.001)\end{array}$ & $\begin{array}{l}0.009 * * * \\
(0.001)\end{array}$ & $\begin{array}{l}0.006 * * * \\
(0.001)\end{array}$ & $\begin{array}{l}0.008 * * * \\
(0.001)\end{array}$ & $\begin{array}{l}0.009 * * * \\
(0.001)\end{array}$ \\
\hline $\log ($ distribution area (lv)) & $\begin{array}{l}0.015 * * * \\
(0.001)\end{array}$ & $\begin{array}{l}0.003 * * \\
(0.001)\end{array}$ & $\begin{array}{l}0.002 \\
(0.001)\end{array}$ & $\begin{array}{l}0.012 * * * \\
(0.001)\end{array}$ & $\begin{array}{l}0.001 \\
(0.001)\end{array}$ & $\begin{array}{l}-0.002 \\
(0.001)\end{array}$ & $\begin{array}{l}0.014 * * * \\
(0.001)\end{array}$ & $\begin{array}{l}0.004 * * * \\
(0.001)\end{array}$ & $\begin{array}{l}0.001 \\
(0.001)\end{array}$ \\
\hline distribution area (lv)/area & $\begin{array}{l}-0.021 * * * \\
(0.002)\end{array}$ & $\begin{array}{l}-0.009 * * * \\
(0.002)\end{array}$ & $\begin{array}{l}-0.001 \\
(0.002)\end{array}$ & $\begin{array}{l}-0.023 * * * \\
(0.002)\end{array}$ & $\begin{array}{l}-0.010 * * * \\
(0.002)\end{array}$ & $\begin{array}{l}-0.004 * \\
(0.002)\end{array}$ & $\begin{array}{l}-0.020 * * * \\
(0.002)\end{array}$ & $\begin{array}{l}-0.009 * * * \\
(0.002)\end{array}$ & $\begin{array}{l}-0.001 \\
(0.002)\end{array}$ \\
\hline share cable & $\begin{array}{l}-0.050 * * * \\
(0.006)\end{array}$ & $\begin{array}{l}-0.067 * * * \\
(0.005)\end{array}$ & $\begin{array}{l}-0.087 * * * \\
(0.005)\end{array}$ & $\begin{array}{l}-0.040 * * * \\
(0.006)\end{array}$ & $\begin{array}{l}-0.066 * * * \\
(0.005)\end{array}$ & $\begin{array}{l}-0.079 * * * \\
(0.006)\end{array}$ & $\begin{array}{l}-0.057 * * * \\
(0.006)\end{array}$ & $\begin{array}{l}-0.069 * * * \\
(0.005)\end{array}$ & $\begin{array}{l}-0.091 * * * \\
(0.005)\end{array}$ \\
\hline $\log (\#$ meter points lv $)$ & $\begin{array}{l}-0.069 * * * \\
(0.005)\end{array}$ & $\begin{array}{l}-0.055 * * * \\
(0.005)\end{array}$ & $\begin{array}{l}-0.053 * * * \\
(0.005)\end{array}$ & $\begin{array}{l}-0.069 * * * \\
(0.005)\end{array}$ & $\begin{array}{l}-0.051 * * * \\
(0.005)\end{array}$ & $\begin{array}{l}-0.047 * * * \\
(0.005)\end{array}$ & $\begin{array}{l}-0.061 * * * \\
(0.005)\end{array}$ & $\begin{array}{l}-0.055 * * * \\
(0.005)\end{array}$ & $\begin{array}{l}-0.047 * * * \\
(0.005)\end{array}$ \\
\hline hv zone Vattenfall & $\begin{array}{l}0.025 * * * \\
(0.006)\end{array}$ & $\begin{array}{l}0.046 * * * \\
(0.005)\end{array}$ & $\begin{array}{l}0.053 * * * \\
(0.005)\end{array}$ & $\begin{array}{l}0.027 * * * \\
(0.006)\end{array}$ & $\begin{array}{l}0.047 * * * \\
(0.005)\end{array}$ & $\begin{array}{l}0.054 * * * \\
(0.005)\end{array}$ & $\begin{array}{l}0.024 * * * \\
(0.006)\end{array}$ & $\begin{array}{l}0.046 * * * \\
(0.005)\end{array}$ & $\begin{array}{l}0.052 * * * \\
(0.005)\end{array}$ \\
\hline hv zone E.On & $\begin{array}{l}-0.023 * * * \\
(0.006)\end{array}$ & $\begin{array}{l}-0.013 * \\
(0.005)\end{array}$ & $\begin{array}{l}-0.011 * \\
(0.005)\end{array}$ & $\begin{array}{l}-0.021 * * * \\
(0.006)\end{array}$ & $\begin{array}{l}-0.012 * \\
(0.005)\end{array}$ & $\begin{array}{l}-0.009 \\
(0.005)\end{array}$ & $\begin{array}{l}-0.024 * * * \\
(0.006)\end{array}$ & $\begin{array}{l}-0.013 * \\
(0.005)\end{array}$ & $\begin{array}{l}-0.011 * \\
(0.005)\end{array}$ \\
\hline hv zone RWE & $\begin{array}{l}0.028 * * * \\
(0.006)\end{array}$ & $\begin{array}{l}0.032 * * * \\
(0.005)\end{array}$ & $\begin{array}{l}0.032 * * * \\
(0.005)\end{array}$ & $\begin{array}{l}0.030 * * * \\
(0.006)\end{array}$ & $\begin{array}{l}0.032 * * * \\
(0.005)\end{array}$ & $\begin{array}{l}0.033 * * * \\
(0.005)\end{array}$ & $\begin{array}{l}0.027 * * * \\
(0.006)\end{array}$ & $\begin{array}{l}0.032 * * * \\
(0.005)\end{array}$ & $\begin{array}{l}0.031 * * * \\
(0.005)\end{array}$ \\
\hline hv zone EnBW & $\begin{array}{l}0.048 * * * \\
(0.006)\end{array}$ & $\begin{array}{l}0.058 * * * \\
(0.005)\end{array}$ & $\begin{array}{l}0.058 * * * \\
(0.005)\end{array}$ & $\begin{array}{l}0.051 * * * \\
(0.006)\end{array}$ & $\begin{array}{l}0.058 * * * \\
(0.005)\end{array}$ & $\begin{array}{l}0.061 * * * \\
(0.005)\end{array}$ & $\begin{array}{l}0.046 * * * \\
(0.006)\end{array}$ & $\begin{array}{l}0.057 * * * \\
(0.005)\end{array}$ & $\begin{array}{l}0.057 * * * \\
(0.005)\end{array}$ \\
\hline constant & $\begin{array}{l}5.905 * * * \\
(0.010)\end{array}$ & $\begin{array}{l}6.461 * * * \\
(0.009)\end{array}$ & $\begin{array}{l}6.794 * * * \\
(0.009)\end{array}$ & $\begin{array}{l}5.904 * * * \\
(0.010)\end{array}$ & $\begin{array}{l}6.465^{* * *} \\
(0.009)\end{array}$ & $\begin{array}{l}6.797 * * * \\
(0.009)\end{array}$ & $\begin{array}{l}5.918 * * * \\
(0.010)\end{array}$ & $\begin{array}{l}6.461 * * * \\
(0.009)\end{array}$ & $\begin{array}{l}6.801 * * * \\
(0.009)\end{array}$ \\
\hline
\end{tabular}


Table 4c: Distribution Charge Equation (continued)

\begin{tabular}{|c|c|c|c|c|c|c|c|c|c|}
\hline \multirow[b]{2}{*}{$\mathrm{kWh}$} & \multicolumn{3}{|c|}{$\begin{array}{c}\log (\# \text { contracts below standard } \\
\text { contract })\end{array}$} & \multicolumn{3}{|c|}{$\log (\#$ providers $)$} & \multicolumn{3}{|c|}{$\begin{array}{c}\log (\# \text { contracts below standard } \\
\text { contract/providers })\end{array}$} \\
\hline & 1500 & 2800 & 4000 & 1500 & 2800 & 4000 & 1500 & 2800 & 4000 \\
\hline $\log ($ distribution area (lv)) & $\mid \begin{array}{l}0.021 * * * \\
(0.003)\end{array}$ & $\begin{array}{l}0.005^{*} \\
(0.002)\end{array}$ & $\begin{array}{l}0.014 * * * \\
(0.002)\end{array}$ & $\mid \begin{array}{l}0.004 \\
(0.003)\end{array}$ & $\begin{array}{l}-0.000 \\
(0.002)\end{array}$ & $\begin{array}{l}-0.001 \\
(0.002)\end{array}$ & $\mid \begin{array}{l}0.020 * * * \\
(0.003)\end{array}$ & $\begin{array}{l}0.011 * * * \\
(0.002)\end{array}$ & $\begin{array}{l}0.011 * * * \\
(0.002)\end{array}$ \\
\hline distribution area (lv)/area & $\begin{array}{l}-0.057 * * * \\
(0.005)\end{array}$ & $\begin{array}{l}-0.053 * * * \\
(0.004)\end{array}$ & $\begin{array}{l}-0.039 * * * \\
(0.004)\end{array}$ & $\begin{array}{l}-0.067 * * * \\
(0.005)\end{array}$ & $\begin{array}{l}-0.055^{* * * *} \\
(0.004)\end{array}$ & $\begin{array}{l}-0.049 * * * \\
(0.004)\end{array}$ & $\begin{array}{l}-0.051 * * * \\
(0.005)\end{array}$ & $\begin{array}{l}-0.049 * * * \\
(0.004)\end{array}$ & $\begin{array}{l}-0.037 * * * \\
(0.004)\end{array}$ \\
\hline $\begin{array}{l}\text { share multi-apartment } \\
\text { houses }\end{array}$ & $\begin{array}{l}-0.036 * * * \\
(0.009)\end{array}$ & $\begin{array}{l}-0.056 * * * \\
(0.007)\end{array}$ & $\begin{array}{l}-0.050 * * * \\
(0.007)\end{array}$ & $\begin{array}{l}-0.050 * * * \\
(0.009)\end{array}$ & $\begin{array}{l}-0.060 * * * \\
(0.007)\end{array}$ & $\begin{array}{l}-0.064 * * * \\
(0.007)\end{array}$ & $\begin{array}{l}-0.034 * * * \\
(0.009)\end{array}$ & $\begin{array}{l}-0.051 * * * \\
(0.007)\end{array}$ & $\begin{array}{l}-0.051 * * * \\
(0.007)\end{array}$ \\
\hline share cable & $\begin{array}{l}-0.419 * * * \\
(0.015)\end{array}$ & $\begin{array}{l}-0.372 * * * \\
(0.013)\end{array}$ & $\begin{array}{l}-0.397 * * * \\
(0.012)\end{array}$ & $\begin{array}{l}-0.399 * * * \\
(0.015)\end{array}$ & $\begin{array}{l}-0.371 * * * \\
(0.013)\end{array}$ & $\begin{array}{l}-0.363^{* * *} \\
(0.012)\end{array}$ & $\begin{array}{l}-0.461 * * * \\
(0.015)\end{array}$ & $\begin{array}{l}-0.386^{* * *} \\
(0.013)\end{array}$ & $\begin{array}{l}-0.415 * * * \\
(0.012)\end{array}$ \\
\hline $\log (\#$ meter points $\mathrm{lv})$ & $\begin{array}{l}-0.328 * * * \\
(0.014)\end{array}$ & $\begin{array}{l}-0.291 * * * \\
(0.012)\end{array}$ & $\begin{array}{l}-0.290 * * * \\
(0.011)\end{array}$ & $\begin{array}{l}-0.308 * * * \\
(0.014)\end{array}$ & $\begin{array}{l}-0.275^{* * *} \\
(0.012)\end{array}$ & $\begin{array}{l}-0.266^{* * *} \\
(0.011)\end{array}$ & $\begin{array}{l}-0.299 * * * \\
(0.014)\end{array}$ & $\begin{array}{l}-0.298 * * * \\
(0.012)\end{array}$ & $\begin{array}{l}-0.271 * * * \\
(0.011)\end{array}$ \\
\hline hv zone Vattenfall & $\begin{array}{l}0.032 * \\
(0.015)\end{array}$ & $\begin{array}{l}0.060 * * * \\
(0.013)\end{array}$ & $\begin{array}{l}0.065^{* * *} \\
(0.012)\end{array}$ & $\begin{array}{l}0.037 * \\
(0.015)\end{array}$ & $\begin{array}{l}0.059 * * * \\
(0.013)\end{array}$ & $\begin{array}{l}0.069 * * * \\
(0.012)\end{array}$ & $\begin{array}{l}0.025 \\
(0.015)\end{array}$ & $\begin{array}{l}0.058 * * * \\
(0.013)\end{array}$ & $\begin{array}{l}0.062 * * * \\
(0.012)\end{array}$ \\
\hline hv zone E.On & $\begin{array}{l}-0.073 * * * \\
(0.015)\end{array}$ & $\begin{array}{l}-0.072 * * * \\
(0.012)\end{array}$ & $\begin{array}{l}-0.080 * * * \\
(0.012)\end{array}$ & $\begin{array}{l}-0.065^{* * *} \\
(0.015)\end{array}$ & $\begin{array}{l}-0.071 * * * \\
(0.012)\end{array}$ & $\begin{array}{l}-0.074 * * * \\
(0.012)\end{array}$ & $\begin{array}{l}-0.077 * * * \\
(0.015)\end{array}$ & $\begin{array}{l}-0.075^{* * *} \\
(0.012)\end{array}$ & $\begin{array}{l}-0.082 * * * \\
(0.012)\end{array}$ \\
\hline hv zone RWE & $\left(\begin{array}{l}-0.023 \\
(0.015)\end{array}\right.$ & $\begin{array}{l}-0.010 \\
(0.013)\end{array}$ & $\begin{array}{l}-0.012 \\
(0.012)\end{array}$ & $\begin{array}{l}-0.019 \\
(0.015)\end{array}$ & $\begin{array}{l}-0.011 \\
(0.013)\end{array}$ & $\begin{array}{l}-0.008 \\
(0.012)\end{array}$ & $\begin{array}{l}-0.031 * \\
(0.015)\end{array}$ & $\begin{array}{l}-0.012 \\
(0.013)\end{array}$ & $\begin{array}{l}-0.015 \\
(0.012)\end{array}$ \\
\hline hv zone EnBW & $\begin{array}{l}-0.191 * * * \\
(0.015)\end{array}$ & $\begin{array}{c}-0.132 * * * \\
(0.013)\end{array}$ & $\begin{array}{l}-0.120 * * * \\
(0.012)\end{array}$ & $\begin{array}{l}-0.182 * * * \\
(0.015)\end{array}$ & $\begin{array}{l}-0.132 * * * \\
(0.013)\end{array}$ & $\begin{array}{l}-0.111^{* * *} \\
(0.012)\end{array}$ & $\begin{array}{l}-0.202^{* * *} \\
(0.015)\end{array}$ & $\begin{array}{l}-0.136^{* * *} \\
(0.013)\end{array}$ & $\begin{array}{l}-0.125^{* * *} \\
(0.012)\end{array}$ \\
\hline constant & $\begin{array}{l}4.768 * * * \\
(0.023)\end{array}$ & $\begin{array}{l}5.241 * * * \\
(0.020)\end{array}$ & $\begin{array}{l}5.538 * * * \\
(0.019)\end{array}$ & $\begin{array}{l}4.797 * * * \\
(0.023)\end{array}$ & $\begin{array}{l}5.261 * * * \\
(0.020)\end{array}$ & $\begin{array}{l}5.552 * * * \\
(0.019)\end{array}$ & $\begin{array}{l}4.819 * * * \\
(0.023)\end{array}$ & $\begin{array}{l}5.237 * * * \\
(0.020)\end{array}$ & $\begin{array}{l}5.567 * * * \\
(0.019)\end{array}$ \\
\hline
\end{tabular}


Table 4d: Summary Statistics (continued)

\begin{tabular}{|c|c|c|c|c|c|c|c|c|c|}
\hline \multirow[b]{2}{*}{$\mathrm{kWh}$} & \multicolumn{3}{|c|}{$\begin{array}{l}\log (\# \text { contracts below standard } \\
\text { contract })\end{array}$} & \multicolumn{3}{|c|}{$\log (\#$ providers $)$} & \multicolumn{3}{|c|}{$\begin{array}{c}\log (\# \text { contracts below standard } \\
\text { contract/providers })\end{array}$} \\
\hline & 1500 & 2800 & 4000 & 1500 & 2800 & 4000 & 1500 & 2800 & 4000 \\
\hline \multicolumn{10}{|l|}{ Observations } \\
\hline competition equation & 4734 & 4725 & 4714 & 4734 & 4726 & 4714 & 4734 & 4726 & 4714 \\
\hline price equation & 4734 & 4725 & 4714 & 4734 & 4726 & 4714 & 4734 & 4726 & 4714 \\
\hline dc equation & 4734 & 4725 & 4714 & 4734 & 4726 & 4714 & 4734 & 4726 & 4714 \\
\hline \multicolumn{10}{|l|}{ Parameters } \\
\hline competition equation & 10 & 10 & 10 & 10 & 10 & 10 & 10 & 10 & 10 \\
\hline price equation & 11 & 11 & 11 & 11 & 11 & 11 & 11 & 11 & 11 \\
\hline dc equation & 9 & 9 & 9 & 9 & 9 & 9 & 9 & 9 & 9 \\
\hline \multicolumn{10}{|l|}{ RMSE } \\
\hline competition equation & 0.109 & 0.113 & 0.110 & 0.067 & 0.065 & 0.064 & 0.082 & 0.085 & 0.087 \\
\hline price equation & 0.032 & 0.028 & 0.029 & 0.032 & 0.028 & 0.029 & 0.032 & 0.028 & 0.029 \\
\hline dc equation & 0.081 & 0.068 & 0.065 & 0.081 & 0.068 & 0.065 & 0.081 & 0.068 & 0.065 \\
\hline \multicolumn{10}{|l|}{$\mathrm{R} 2$} \\
\hline competition equation & 0.914 & 0.893 & 0.895 & 0.737 & 0.748 & 0.759 & 0.925 & 0.904 & 0.900 \\
\hline price equation & 0.494 & 0.572 & 0.581 & 0.495 & 0.572 & 0.582 & 0.493 & 0.572 & 0.581 \\
\hline dc equation & 0.528 & 0.570 & 0.585 & 0.526 & 0.569 & 0.585 & 0.526 & 0.571 & 0.584 \\
\hline
\end{tabular}

Note: Estimation Results using 3SLS method

$*, * *, * * *$ represent significance at the 10,5 and 1 percent significance levels, respectively. 